\title{
Biochar: carbon sequestration, land remediation and impacts on soil microbiology
}

\section{Short title: Biochar: carbon, \& microbial impacts}

Christopher J. Ennis, ${ }^{1}$ A. Garry Evans, ${ }^{1}$ Meez Islam, T. Komang Ralebitso-Senior, Eric Senior. ${ }^{1 *}$

Clean Environment Management Centre, ${ }^{1}$ School of Science and Engineering, Teesside University, Middlesbrough, Tees Valley, TS1 3BA, United Kingdom.

*Author to whom correspondence should be addressed: e.senior@tees.ac.uk; +44 (0) 1642384314

\begin{abstract}
Biochar - charcoal used to amend land and sequester carbon - is attracting considerable interest. Its distinctive physical/chemical/biological properties, including high water-holding capacity, large surface area, cation exchange capacity, elemental composition and pore size/volume/distribution, effect its recognised impacts, especially on microbial communities. These are explored in the context of agriculture, composting and land remediation/restoration. Considerable focus is given to mycorrhizal associations, which are central to exploitation in environmental technologies involving biochar. The characteristics of biochar, its availability for nutrient cycling, including the beneficial and potentially negative/inhibitory impacts, and the requisite multidisciplinary analysis (physico-chemical, microbiological and molecular) to study these in detail, are explored.
\end{abstract}

\section{Introduction}

Interest in 'biochar', 1 the application of charcoal to land, is led by the dual benefits of long term carbon sequestration and potentially positive soil amendment (Dover, 2007; Lal 2009; Tenenbaum, 2009). In particular, the ability of biochar to act as a feasible climate change mitigation technology, implementable at globally significant scale, is recognised (Molina et al., 2009), with the potential to sequester the equivalent of up to $12 \%$ of anthropogenic greenhouse gas emissions (Woolf et al., 2010) in ecologically and economically sustainable systems. A key constraint to the commercialisation of the technology is the addition of sufficient value to charcoal to prevent its combustion for traditional applications as a fuel and reductant.

\footnotetext{
${ }^{1}$ For the purposes of this review 'biochar' refers to char (charcoal) that has been, or is intended to be, applied to land.
} 
Proposed benefits in agricultural systems (soil enrichment, reduced input requirement, enhanced yields, land remediation/reclamation) and carbon trading are now being investigated as potential sources of sufficient added value. The pyrolysis process can be tailored in terms of feedstock and conditions to produce chars with desired qualities for specific applications (Dover, 2007). Sustainable systems have been postulated (Mathews, 2008; Preston, 2009; Lee et al., 2010) in which biomass is used to simultaneously produce energy and charcoal, which, upon application to land, removes carbon from the short term photosynthesis-mediated cycle to a long term reservoir. Hence, energy so generated is potentially certifiably carbon negative and can act as a source of revenue from not only its sale but also the generation of tradable carbon credits (Mathews, 2008).

The climate change benefits of biochar depend critically on both the lifetime of the charcoal in soil and the overall life cycle impacts of its production and application. A life cycle analysis of biochar systems made by Roberts et al. (2010) highlighted the critical nature of the source material and bioenergy production in realising climate change benefits. Indirect land use change emissions from dedicated crops have the potential to produce net greenhouse gas (GHG) emissions whereas biochar systems with waste or agricultural residues as feedstock provide net carbon sinks, around two thirds of which arise due to carbon sequestration in the biochar. Economic sustainability depends critically on: transport distances; market values for carbon reduction credits; and bioenergy yields. The additional bioenergy available from fast pyrolysis systems makes these more economically viable, therefore, than slow pyrolysis routes to biochar: Brown et al. (2011) have demonstrated an internal rate of return as high as $15 \%$ by 2015 , rising to greater than $25 \%$ in 2030 , based upon underlying assumptions about the cost of feedstocks and carbon credits. These considerations are especially critical if agricultural waste is the pyrolysis feedstock. Production costs for dedicated energy crops render such biochar uneconomical.

Despite its inherent recalcitrance and limited accessibility through soil particle envelopment (Brodowski et al., 2006) acting as a barrier to enzymes (Ekschmitt et al., 2008), the impacts of biochar on soil biogeochemistry (Liu et al., 2009) and microbial activity are limited by its ultimate mineralization which can vary from thousands of years (Fowles, 2007; Kuzyakov et al., 2009; Grossman et al., 2010) to decades in well aerated tropical soils (Bird et al., 1999). Nguyen and Lehmann (2009) considered, therefore, whether water regimes typical of tropical soils (saturated, unsaturated, and alternating saturated/unsaturated) exerted different effects on the degradation of two biochars (Zea mays and Quercus spp.) produced at 350 and $600^{\circ} \mathrm{C}$. They found that the moisture regime was critical in mineralization (characterized by increased carboxylic and $\mathrm{OH}$ functional groups but decreased aliphatic groups) of Zea mays stover residue and Quercus spp shavings biochar under unsaturated and saturated/unsaturated 
conditions, respectively. They attributed this to oxygen availability for abiotic/biotic oxidation and decomposition (Morris et al., 2004). Of the two water regimes, saturated/unsaturated conditions often promote the higher mineralization ( $\mathrm{Wu}$ and Brookes, 2005) through soil particle disaggregation (Denef et al., 2001), nutrient availability (Binh and Marschner, 2005), microbial activity (Gordon et al., 2008) or microbial biomass turnover (Van Gestel et al., 1991). Since for both plant types, carbon loss correlated strongly with O/C value changes, it was concluded that biochar oxidation was the strongest stability controlling determinant. For the corn stover, the higher charring temperature effected reduced mineralization and oxidation but this was not apparent for the oak.

Together with microbial catabolism and key physico-chemical variables, co-metabolism must also be considered as an important driver of mineralization. To examine this, Kuzyakov et al. (2009) added ${ }^{14} \mathrm{C}$-labelled ryegrass (Lolium perenne) biochar produced at $400^{\circ} \mathrm{C}$ to Haplic Luvisol soil $\left(20 \% \mathrm{w} / \mathrm{w}\right.$ of the $\mathrm{C}_{\text {org }}$ ) and loess (approaching $200 \% \mathrm{w} / \mathrm{w})$ followed by regular supplementations of glucose $\left(2.16 \mathrm{mg} \mathrm{g}^{-1}\right.$ soil) over a period of 1089 days with biochar decomposition estimated through ${ }^{14} \mathrm{CO}_{2}$ evolution. In the absence of glucose and even with intensive mixing, decomposition accounted for as little as $0.5 \%$ of the biochar per annum. With glucose, however, six-fold increases were recorded for the soil and loess but these decreased after two weeks and three months, respectively, which led the workers to conclude that co-metabolic decomposition was operative. Microbial analysis showed that

${ }^{14} \mathrm{C}$ was incorporated into cell biomass while dissolved organic carbon assay revealed an absence of biochar decomposition product leaching.

Lehmann et al. (2009) suggested a double-exponential decay model for biochar carbon loss in soil in which two first order loss processes occur simultaneously: rapid decay (half-life, $\lambda \approx 0.54$ years) of labile carbon; and slow ( $\lambda$ $\approx 1,600$ years) mineralisation of fixed biochar carbon. To determine in situ longevity, Nguyen et al. (2009) studied long-term qualitative/quantitative changes in forest fire recovered cultivated western Kenyan soil dating back 100 years. Seventy per cent losses were recorded in the first 30 years after deposition, which they attributed to decomposition and transport with oxidation (Cheng et al., 2008) the dominant factor. The losses then slowed to reach a final concentration ( $3.5 \mathrm{mg} \mathrm{C} \mathrm{g}^{-1}$ soil) of $27.5 \%$ of the original, broadly in line with the double exponential decay hypothesis.

Steinbeiss et al. (2009) also examined biochar residence in soil. They used greenhouse soil (Eutric Fluvisol and Cambisol) columns $\left(150 \mathrm{~g}, 25^{\circ} \mathrm{C}\right.$ day $/ 20^{\circ} \mathrm{C}$ night) with hydrothermally produced ${ }^{13} \mathrm{C}$ glucose and ${ }^{13} \mathrm{C}$ yeast chars (30\% initial organic carbon content) and recorded respiratory losses of soil and biochar carbon. Mean residence times of between four (glucose biochar/arable soil) and 29 years (yeast biochar/arable soil) were determined with 
the variation accounted for by soil type and biochar quality. As short experiments preferentially probe the kinetics of the rapid decay processes these apparently short mean residence times could have been due to the short timeframe of the experiment. Also, hydrothermal material produced from corn stover (Fuertes et al., 2010) and cherry wood (unpublished results from our laboratory) has a relatively high proportion of aliphatic and carboxy/carbonyl functionality; features expected to increase biological and chemical decomposition rates. Peng et al. (2011) reported that as well as increasing aromatic carbon and reducing the $\mathrm{O} / \mathrm{C}$ ratio, increased prolysis temperature also increases estimated lifetime.

In addition to the uncertainties surrounding biochar carbon soil-lifetime there is some debate regarding charcoal's effect on native soil organic carbon stocks. Wardle et al. (2008) observed apparent carbon loss from humus in soil/biochar mixtures consistent with charcoal promoting soil microbial growth and, hence, humic decomposition. This loss of soil carbon may offset the GHG sequestration benefits of biochar to some extent possibly due to oxidation of labile biochar components rather than accelerated loss of native soil organic matter (Lehmann and Sohi, 2008). Indeed, Kimetu and Lehmann (2010) have subsequently demonstrated that biochar addition stabilises soil organic carbon better than green manure labile carbon. Tithionia diversifolia green manure additions increased $\mathrm{CO}_{2} \mathrm{C}$ loss by $22 \%$ while biochar addition reduced soil $\mathrm{CO}_{2}$ carbon loss by $27 \%$ and increased intraaggregate C per respired C by 6.8 times relative to the green manure. In the longer term, Downie et al. (2011), studying soils in ancient Australian Aboriginal oven mounds, showed that historic charcoal additions, between 650 and 1609 years old, resulted in long-lived, significantly elevated soil carbon stocks, relative to the adjacent soil.

Uncertainties regarding climate notwithstanding, compelling evidence of the impact longevity of biochar in soil was gained by Grossman et al. (2010) from molecular analysis (denaturing gradient gel electrophoresis, terminal restriction fragment length polymorphism, cloning and sequencing) of Terra Preta Brazilian Anthrosols and adjacent non-Anthrosol soils. For archaea, the divergence was $>90 \%$ with higher richness and very similar fingerprints generally observed for bacteria of the four studied Anthrosols. From this they concluded that the strongest determinant of microbial community composition was management by the pre-Colombian Indians rather than soil type or land use. 
Agricultural benefits arising from biochar are varied and of presently uncertain and probably complex mechanisms. Reviews by Sohi et al. (2010), Atkinson et al. (2010) and Joseph et al. (2010) have detailed the agricultural implications of biochar and its mechanistic aspects. In this review we briefly discuss the production and characterisation of char and outline the benefits that have been reported before moving on to highlight aspects of mechanisms that are mediated by microbial community responses to biochar amendment. In addition, we consider the potential utility of biochar in composting and microbiological remediation of contaminated land.

\section{Char physico-chemical characterisation}

Anaerobic thermal conversion of biomass can be achieved in three different processes: pyrolysis/carbonisation; gasification; and liquefaction. All three give products in three phases, solid, liquid and gas, with the product composition dependent on process conditions. Thus, pyrolysis is characterised by long residence times and moderate temperatures, liquefaction occurs under high heating rates, while gasification is defined by high temperatures, often with additional, though sub-stoichiometric, oxygen.

Pyrolysis typically produces a solid, structured, carbonaceous material which, compared to the feedstock, exhibits a high surface area (Bird et al., 2008), reduced oxygen and hydrogen content (Abdullah and Wu, 2009), and a concentration of nutrients (Agblevor et al., 2010; Gaskin et al., 2008).

Key properties of biochar, such as $\mathrm{pH}$, surface area, volatiles, ash, bulk density and pore-volume, water holding capacity, are sensitive functions of pyrolysis feedstock and process conditions. Surface area is readily discernable via classical adsorption techniques, such as $\mathrm{N}_{2}$ adsorption analysed by the Brunauer-Emmett-Teller (BET) adsorption isotherm (Lua et al., 2004; Brown et al., 2006), while proximate analysis provides quantification of volatile and fixed carbon, as well as residual ash (Antal et al., 2000). Reviews by Atkinson et al. (2010) and Joseph et al. (2010) summarised the effect of pyrolysis temperature on these properties and the subsequent interactions in soil. The chemical environment of the fixed carbon can be probed by a variety of solid phase ${ }^{13} \mathrm{C}$ nuclear magnetic resonance techniques (Sharma et al., 2004; Cheng et al., 2006; Brewer et al., 2009). Char chemistry and surface functionality can be assessed by various techniques including titrimetrically (Boehm, 1994) and spectroscopically by vibrational techniques such as infrared (Sharma et al., 2004; Cheng et al., 2006) and electron energy loss (Cohen-Ofri et al., 2007) spectroscopies. Such investigations demonstrate that biochar properties are a complicated function of feedstock nature (identity, form, etc.) and pyrolytic conditions. 
Both mass yield and the degree of aromaticity are functions of feedstock and pyrolysis conditions. Temperature, heating rate, sweep-gas flow rate and feedstock particle size are all factors that affect the mass yield of biochar. Özçimen and Ersoy-Meriçboyu (2008) investigated the effect of highest treatment temperature, heating rate and sweep gas flow rate in a $2^{3}$ factorial design experiment and found that temperature was the dominant parameter. Similar temperature-induced yield decreases have been reported for pyrolysis of animal residues (Ayllón et al., 2006; Yilmaz et al., 2007), cottonseed cake (Özbay et al., 2001), pinewood bark (Şensöz, 2003), rapeseed (Onay and Koçkar, 2003), sugarcane bagasse (Katyal et al., 2003) and sunflower cake (Gerçel, 2002). Increased sweep gas flow rate, increased heating rate and decreased particle size all lead to decreased char production (Özyurtkan et al. (2008), with the former exerting the slightly stronger effect. This indicates that reaction yield is governed by reaction kinetics and thermal and mass transfer considerations.

Temperature (Brewer et al., 2009) and time at temperature (Yip et al, 2011) increase the extent of aromatic structure formation in biochar. Aromaticity is an important determinant of biochar quality in particular contexts. Low aromaticity and small aromatic cluster size implies high surface functionality compared to material characterized by larger aromatic regions, and leads to higher cation exchange capacity in soil (Joseph et al., 2009). This contrasts the increased water retention capacity of elevated temperature material due to higher surface area. On the other hand, a rise in char aromaticity leads to greater recalcitrance in soil with concomitantly protracted sequestration potential. Also, high temperature biochar exhibits high surface area and porosity, both of which can be exploited in adsorption-based remediation technologies.

Just as pyrolysis conditions time alter the properties of the char, so too does the feedstock. The results of studies in Table 1 highlight the range of biochar properties achieved as a function of temperature and feedstock identity. Optimisation of parameters for any given feedstock and application, although a challenge, offers the potential for bespoke biochar tailored for specific resources and applications.

Together with traditional char feedstocks, alternatives have been investigated. Of particular interest, given the thrust of biochar research towards climate change mitigation, is char production from agricultural residues. Carbon rich chars have been produced by pyrolysis of residues of rapeseed (Karaosmanoğlu et al., 2000), rape and sunflower (Sánchez et al., 2009a) under a variety of temperatures and heating rates, while agricultural wastes of relevance in a Turkish context have been investigated widely (Özçimen and Karaosmanoğlu, 2004; Özçimen and Ersoy-Meriçboyu, 2008; Özçimen and Ersoy-Meriçboyu, 2010). Also, pyrolysis of sewage sludge has been shown to generate a good quality char (Sánchez et al., 2009b; Hossain et al., 2011) while casein (Purevsuren et al., 2003) 
gives a highly porous product (content of porosity $=20 \%)$ with a high nitrogen content $(9.02 \%$ w/w). Even microalgae have been demonstrated to produce high yields ( $>1 / 3$ by mass) (Grierson et al., 2009).

In addition to classical pyrolysis processes for char production, alternative routes have been explored. These include hydrothermal carbonisation (Worasuwannarak et al., 2006; Steinbeiss et al., 2009; Fuertes et al., 2010), pressurised pyrolysis (Mahinpey et al., 2009) and microwave pyrolysis (Lei et al., 2009). These latter processes have potential as routes to materials with properties outside the range of normal pyrolysis products and/or higher energy efficiency.

\section{Agricultural applications}

Research on Terra Preta (black earth) - anthropogenically modified Brazilian Oxisols - is well documented (Glaser et al., 2003; Glaser, 2007) with its fertility recognised as long ago as the 16th century (Abend, 2008). Although the efficacy of biochar to promote plant growth (Yamato et al., 2006; Chan et al., 2007a; Steiner et al., 2007a) through, for example, increases in total carbon (van Zwieten et al., 2010), nutrient retention/availability (Asai et al., 2009; Sánchez et al., 2009a), soil moisture holding capacity/permeability (Gathorne-Hardy et al., 2008; Busscher et al., 2010), organic matter and pH, and promoted microbial activity (Chan et al., 2007a), is well recognised, few definitive studies have yet been reported even though, since 2000, global food demand has outstripped supply. Work is, however, in progress globally with different starting materials, production conditions, soil types, loadings, plant species and fertilizer applications (organic/inorganic).

Reviews by Sohi et al. (2010) and Atkinson et al. (2010) have assessed in some detail the impacts of biochar on agricultural productivity and its potential mechanisms. Briefly, biochar application exerts chemical effects, such as soil $\mathrm{pH}$ alteration (Chan et al., 2008; Rodríguez et al., 2009; van Zwieten et al., 2010), changes in cationic properties (Steiner et al., 2007b; Nguyen and Lehmann 2009; Novak et al., 2009), increased availability of N and P (Sánchez et al., 2009a; Hossain et al., 2010), reduced leaching loss of ammonium (Ding et al., 2010), increased organic carbon (Chen et al., 2008, Novak et al., 2009; van Zwieten et al., 2010) and interactions with applied nutrients. Representative results from short-term studies are presented in Table 2. In some cases, significant negative interactions have been observed through, for example, adverse $\mathrm{pH}$ alterations (Mikan and Abrams, 1996; van Zwieten et al., 2010) or the action of adsorbed phytotoxic pyrolysis oils (Gell et al., 2011). Biochar addition also alters soil physical properties with water holding capacity (Iswaran et al., 1980; Gathorne-Hardy et al., 2008; Busscher et al., 2010), soil humidity (Steiner et al., 2007b) and top soil saturated hydraulic conductivity (Asai et 
al., 2009) all increased, while soil strength decreased (Chan et al., 2007a, 2008; Busscher et al., 2010). These effects underpin the short term responses observed in the studies in Table 1.

This complex, and potentially synergic (Steiner et al., 2007a; van Zwieten et al., 2010), combination of physical and chemical changes in the soil environment does not account fully for the observed effects on yield. For example, Kimetu et al. (2008), in the Western Kenyan Highlands, investigated whether maize crop declines (through continuous cultivation over 100 years) even in the presence of nitrogen-phosphorus-potassium (120-100$100 \mathrm{~kg} \mathrm{ha}^{-1}$ ) fertilization could be reversed by the addition of biochar. For most degraded sites, maize productivity doubled although this was not accounted fully by enhanced nutrient availability. Similarly, Chan et al. (2007a; 2008) attributed plant dry matter yield enhancements in the presence of both biochar and fertilizer to enhanced nitrogen fertilizer use efficiency. Furthermore, the promotion of microbial activity by biochar-induced increases in soil humidity, $\mathrm{pH}$, total nitrogen and the availability of sodium, zinc, copper and manganese was reported by Steiner et al. (2007b). They examined the growth of bananas (Musa sp.) and guarana (Paullinia cupana) on Amazonian upland soil subjected to nitrogen and phosphorus additions through both organic and inorganic fertilizers. Marked increases in basal respiration and microbial efficiency were seen in response to the biochar. Enhanced biological nitrogen fixation rates observed by Rondon et al. (2007) were attributed to the increased availability of boron and molybdenum and, to a lesser extent, the improved availability of potassium, calcium and phosphate together with the elevated $\mathrm{pH}$, lower nitrogen availability and aluminium saturation.

Applications (0-90 $\mathrm{g} \mathrm{kg}^{-1}$ soil) were used to examine nitrogen fixation (isotope dilution method with $\left.\left({ }^{15} \mathrm{NH}_{4}\right)_{2} \mathrm{SO}_{4}\right)$ by common beans (Phaseolus vulgaris L.) (Rondon et al., 2007). With biochar (90 $\left.\mathrm{g} \mathrm{kg}^{-1} \mathrm{soil}\right)$, the fixed nitrogen proportion increased from $50 \%$ (control) to $72 \%$. Increases in the total nitrogen derived from the atmosphere were recorded for $30 \mathrm{~g} \mathrm{~kg}^{-1}$ soil (49\%) and $60 \mathrm{~g} \mathrm{~kg}^{-1}$ soil (78\%) but these decreased to $30 \%$ with the highest concentration due to low total biomass production and nitrogen uptake. The workers concluded that the biocharmediated elevated biological nitrogen fixation was due to the increased availability of boron and molybdenum and, to a lesser extent, the improved availability of potassium, calcium and phosphate together with the raised $\mathrm{pH}$, lower nitrogen availability and aluminium saturation. In contrast to the nitrogen derived from the atmosphere, soil nitrogen uptake decreased by 14 and $17 \%$ in the presence of biochar additions of 30 and $60 \mathrm{~g} \mathrm{~kg}^{-1} \mathrm{soil}^{\mathrm{i}}$, respectively. Although the results demonstrated clearly that biochar can promote agroecosystem nitrogen input, further studies are required to underpin this practice. 


\section{Composting}

Sustainable physical, chemical and biological properties of soil (Westerman and Bicudo, 2005) rely on continual applications of stabilised compost to reduce erosion, dampen temperature fluctuation, improve water infiltration/retention, control pathogenicity, and provide essential plant nutrients (Hoitink, 1993). Realization of such a product is achieved, in part, by preventing compaction of the compost by the provision of a bulking agent, which supplies carbon and energy (Adhikari et al., 2009) and increases the porosity (Walker, 1993) and, thus, air voids of the pile (Huag, 1993). Since the provision of labile carbon should reduce nitrogen losses, a bulking agent, which supplies this but is dominated by humification-enhancing recalcitrant molecules (Goyal et al., 2005) would be ideal. Although the physical and chemical properties of biochar would commend its use as a bulking agent, this possibility has received little attention (Hua et al., 2009; Dias et al., 2010).

Dias et al. (2010) prepared mixtures (1:1 fresh weight) of poultry manure with three different bulking agents, coffee husks, sawdust and Eucalyptus grandis biochar, for turned-pile composting (30 weeks) with moisture control. Due to the recalcitrance and high hydrophobicity (Trompowsky et al., 2005) of the carbon, the poultry manure/biochar compost recorded high humification with the humic acids dominating the fulvic acids. Organic matter degradation $>70 \%(\mathrm{w} / \mathrm{w})$ was, however, recorded and the workers attributed this to microbial catabolism and temperature-promoted abiotic oxidation which, in turn, enhanced further catabolism. The lability of the biochar (Baldock and Smernik, 2002) can be attributed to its method of production (slow, $300-450^{\circ} \mathrm{C}$ pyrolysis). The alkaline $\mathrm{pH}$ of the final product commended its use as an acid-correcting soil conditioner although its postsoil application nutrient cycling and humification still require examination particularly in comparison with biochar-free compost additions.

\section{Land restoration/reclamation}

\subsection{The roles of mycorrhizas}

With a research history of 125 years since Frank first termed the higher plant root/fungal interaction 'mycorrhiza', it is unsurprising that an extensive literature exists on these associations. Since the 1970s it has been accepted that most plants are mycorrhizal, commonly arbuscular mycorrhizal or ectomycorrhizal, with the association benefitting the plant by enhancing tolerance to stresses such as drought, salinity, low nutrient (through, for example, promoted phosphorus uptake (Gunderson et al., 2007; Juwarkar and Jambhulkar, 2008)), disease, toxic organic contaminants and heavy metals, and improving soil structure in general (Li et al., 2006), through soil particle formation and aeration promotion, increased legume nitrogen fixation and reduced nutrient leaching 
(Mason, 2004). The earlier observations, in turn, stimulated consideration of applications in agriculture (Kendrick and Berch, 1984), forestry (Mexal, 1980) and derelict, degraded and contaminated land restoration/reclamation (Williams and Aldon, 1976; Gardner and Malajczuk, 1988).

Largely driven by economics, rather than pollution amelioration per se, land reinstatement continues to attract much research attention. For example, amelioration of heavy metal/metalloid contaminated land (Azcón et al., 2009; Lebeau et al., 2008; Marques et al., 2009) with respect to single chemical species (Cd (Janoušková et al., 2006; Hu et al., 2007; Gonzalez-Chavez et al., 2009); As (Jankong and Visoottiviseth, 2008; Smith et al., 2010b)), radioactive contamination (uranium (Dupré de Boulois et al., 2008a); radiocaesium (Dupré de Boulois et al., 2008b)), binary heavy metal systems (Cd/Zn (Krpata et al., 2009; Rashid et al., 2009); Cu/Pb (Huang et al., 2000)) and heavy metal components of generic waste such as fly ash $(\mathrm{Cd} / \mathrm{Cu} / \mathrm{Ni} / \mathrm{Pb}$ (Juwarkar and Jambhulkar, 2008; Haynes, 2009)) or tannery effluent (Cr (Khan, 2001)) are active areas of research. Application to the remediation of organics such as petroleum (Lin et al., 2006; Chen et al., 2009), diesel (Gunderson et al., 2007), petrochemical wastes (De Paula et al., 2006) and polycyclic aromatic hydrocarbons (Joner et al., 2001; Joner and Leyval, 2003; Li et al., 2006) such as phenanthrene (Wu et al., 2008a), polychlorinated biphenyls (Chen et al., 2005a), phthalic esters (Wang et al., 2004; Chen et al., 2005b), 3-chlorobenzoic acid (Dittman et al., 2002), and chlorinated phenols, toluene, tetrachloroethylene and 2,4-dichlorophenol (Meharg and Cairney, 2000) continue to be investigated. Insecticides (DDT (Wu et al., 2008b); chlorpyrifos (Korade and Fulekar, 2009)), fungicides (chlorothalonil (Zhang et al., 2007)), herbicides (atrazine (Huang et al., 2007a); triclorpyr, imazapyr and sulfometuron methyl (Busse et al., 2004)) and pharmaceutics such as paracetamol (Khalvati et al., 2010) are also the focus of potential remedial applications of mycorrhizal associations.

Mycorrhizal plants serve important roles through phytoextraction and phytostabilization (Vassilev et al., 2004) and, for heavy metals, the effect exerted depends on contaminant concentration; phytoextraction is operative at low concentrations while reduced bioavailability, through fungal metal binding, is prevalent with high concentrations (Audet and Charest, 2007). The roles of mycorrhiza fungi in combating the challenges of toxic organic molecules can be quite varied. First, the fungus must counter the possibilities of reduced spore germination, root colonization rate and hyphal growth, and the indirect effect of inhibited carbohydrate translocation from the plant (Wang et al., 2006). Once overcome, soil organic pollutant attenuation could result through root accumulation (Huang et al., 2007a). Alternatively, mineralization can occur directly, from fungal catabolism and enzymatic degradation by the constituent enzymes of arbuscular mycorrhizal exudates, or 
indirectly, by enhanced root exudation stimulating catabolic rhizospheric microbial activity with this effect diminishing with distance from the root (Joner and Leyval, 2003). Alternatively, the molecule could be taken up by the plant and accumulated (Li et al., 2006). For a phthalic ester such as di(2-ethylhexyl) phthalate, however, it has been shown (Chen et al., 2005b) that the arbuscular mycorrhizal fungus not only catabolises the molecule but also inhibits its uptake and translocation from the roots to the aerial structures (Wang et al., 2004).

\subsubsection{Mycorrhizas and biochar}

Although the efficacies of mycorrhizas are well documented for phytoextraction and phytostabilization, the literature base is still limited when biochar applications are considered in relation to these amelioration approaches. In laboratory studies, Liiri et al. (2007) used acidic coniferous forest soil to examine the impacts of wood ash addition (5 $\left.000 \mathrm{~kg} \mathrm{ha}^{-1}\right)$ on the growth of ectomycorrhizal Scots pine (Pinus sylvestris L.) seedlings in the presence of enchytraeid worms (Cognettia sphagnetorum). In contrast to an earlier report by Mahmood et al. (2003) of positive impacts on ectomycorrhizal spruce seedlings, the wood ash was found to have a negative effect on seedling biomass which was not overcome by either the mycorrhizal fungi or worms alone but only by the two together thus emphasising the complexity of soil interactions. A critical factor of all additions to soils is the possibility of creating unfavourable nutrient ratios (Wallstedt et al., 2002) by, for example, adding a high $\mathrm{C} / \mathrm{N}$ ratio biochar with a labile fraction nitrogen sink.

In contrast, and although not recorded in terms of improved seedling biomass, workers have reported both stimulated mycorrhizal fungus spore germination (Rillig et al., 2010) and increased root colonisation in response to biochar (Matsubara et al., 2002; Yamato et al., 2006; Ishii and Kodoya, 2007; Warnock et al., 2007; Rillig et al., 2010) or activated carbon (Herrmann et al., 2004) supplementation probably through enhanced nutrient availability (Ishii and Kadoya, 1994) due to improved soil physico-chemical properties (DeLuca et al., 2006).

A review of mycorrhizal responses to biochar was made by Warnock et al. (2007) who considered the possible synergy for promoting soil quality by examining critically four mechanistic hypotheses for its effects on mycorrhizal abundance and/or functioning:

Alteration of soil physico-chemical properties particularly nutrient availability. Although biochar contains limited concentrations of nutrients (Lehmann et al., 2003a; Topoliantz et al., 2005; Gundale and DeLuca, 2006), which could promote fungal proliferation in nutrient poor soils (Treseder and Allen, 2002), both increases (Gundale and DeLuca, 2006) and decreases (Lehmann et al., 2003a) in, for example, available nitrogen, and increases in 
phosphorus (Garcia-Montiel et al., 2002) have been recorded following supplementations with the increases facilitated, in part, by the hyphae minimising losses (Allen, 2007). In addition, as discussed by Warnock et al. (2007), biochar additions can affect the principal interrelated soil physico-chemical factors of $\mathrm{pH}$ (increases/decreases), cation exchange capacity (increases), water holding capacity (increases), bulk density (decreases) and adsorption (increases).

Mycorrhizal fungi/soil bacteria interactions. Warnock et al. (2007) considered the various interactions between mycorrhizal fungi and soil bacteria and identified the important provision of bacterial metabolites (flavanoids, furans and raffinose), which promoted hyphal growth and subsequent root colonization. The authors also considered mineral provision through, for example, bacterial phosphate solubilisation (Kothamasi et al., 2006) as a key factor. The effects of biochar on these interactions remain to be resolved although Warnock et al. (2007) speculated that the supplement may provide nutrients and/or reduced carbon compounds, either directly or indirectly through adsorption. The provision of a high surface area for microbial attachment and growth could also be an important element.

Plant-fungus signalling interference and biochar attenuation of allelochemicals. Signalling between mycorrhizal fungi and the host plant is a feature of the rhizosphere (Harrison, 2005). Key plant root secretion compounds include carbon dioxide, flavanoids, sesquiterpenes and strigolactones (Warnock et al., 2007). Biochar addition could, therefore, exert both direct (adsorption/desorption of signalling compounds or inhibitory allelochemicals/toxic molecules) and indirect ( $\mathrm{pH}$ change) effects. Although the provision of a sink for fungicidal molecules would promote growth and root colonization, the adsorption of chemical signals would be disadvantageous.

Provision of physical protection against fungal grazers. As discussed above, the physical properties of different biochars can vary with respect to cation sorption capacity (Gundale and DeLuca, 2006) and pore distribution with pore diameters $>16 \mu \mathrm{m}$ reported (Hockaday et al., 2007). Whilst providing surfaces for attachment and growth (Samonin and Elikova, 2004), pore colonisation can afford protection against grazing species (Pietikäinen et al., 2000; Warnock et al., 2007). Although the aromatic fused ring clusters convey considerable recalcitrance to biochar, with accepted estimates for soil residence times of 5000 to 10000 years (Swift, 2001; Krull et al., 2003), both pore sizes and porosity can change through, for example, organic matter adsorption (Kwon and Pignatello, 2005). In well aerated tropical soil, however, residence times of $<100$ years have been estimated (Bird et al., 
1999) with mineralization attributed to microbial catabolism (Hamer et al., 2004) and abiotic oxidation (CohenOfri et al., 2007).

The efficacy of biochar to promote arbuscular mycorrhizal fungal abundance in roots (percent colonisation) must be questioned following the results of a comprehensive study made by Warnock et al. (2010) who examined this together with soil abundance (hyphal length). The host plant was Plantago lanceolata while three different soil types and five biochars and ten applications were used. For all supplementations, root fungal abundance remained either unchanged or decreased. The latter was recorded for Pinus contorta Douglas ex. Louden wood, and was accompanied by decreases in soil phosphorus availability, and both peanut shell and mango wood biochars, which were characterised by phosphorus increases. Elevated plant biomass production was recorded for a single treatment only. These results contrasted earlier studies (Matsubara et al., 2002; Yamoto et al., 2006) where increased abundances were recorded. To find an explanation for their results, Warnock et al. (2010) considered the key variables of $\mathrm{pH}$, phosphate availability, decreased soil organic matter decomposition through biochar sorption and phenolics/polyphenolics -cidal/-static effects and highlighted that considerable work still needs to be done before biochars can be used with confidence in land restoration/reclamation programmes.

Although this discussion has focussed on mycorrhizal fungi, it must be recognised that biochar can be a determinant of both pathogenic and saprophytic fungal activities. Matsubara et al. (2002), for example, demonstrated that tolerance of asparagus seedlings to Fusarium oxysporum was enhanced by the presence of biochar although fresh organic matter gave comparable results. Elad et al. (2010) reported similar results but with citrus wood charcoal when $1-5 \%(\mathrm{w} / \mathrm{w})$ supplementations of sandy soil were found to convey systemic resistance of pepper and tomato to Botrytis cinerea (grey mould) and Leveillula taurica (powdery mildew) and pepper to the mite Polyphagotarsonemus latus Banks. The continued efficacy of biochar is, in turn, dependent on saprophytic fungal activity which, through extracellular enzymic activity and hyphal growth/penetration, can violate the integrity of the material.

\subsection{Soil/sediment remediation}

The ability of biochars to abate soil/sediment pollutants through sorption and sequestration has been recognised increasingly (Bornemann et al., 2007; Nguyen et al., 2007; Chen et al., 2008; Yu et al., 2010; Chen and Yuan, 2011) with high microporosity and surface area and heterogeneous surface physico-chemical properties (James et al., 2005) the key factors (Lohmann et al., 2005; Yu et al., 2006). 
Pesticides. An insight of the possible role of biochar in mitigating the genotoxicity of pentachlorophenol in sediments was given by Cui et al. (2009). With a concentration of $200 \mu \mathrm{g} \mathrm{kg}^{-1}$, the molecule exerted genotoxicity effects on the target species earthworm (Eisenia fetida) but these decreased with increased concentrations of crop residue ash black carbon. The workers cautioned, however, that high concentrations of ash black carbon (10\%) also exerted genotoxicity as recorded by an increased DNA lesion. Later work by Lou et al. (2011) with rice straw biochar showed that pesticide concentrations of $50 \mathrm{mg} \mathrm{kg}^{-1}$ sediment reduced markedly wheat seed growth but a biochar supplementation of $2 \%(\mathrm{w} / \mathrm{w})$ increased both the germination rate and root elongation, which they equated to an extraction liquid PCP concentration reduction from 4.53 to $0.17 \mathrm{mg} l^{-1}$ thus commending the adsorption remediation approach.

As a commonly used herbicide in New Zealand silviculture, terbuthylazine was the target molecule of Wang et al. (2010) in their studies of sorption in two pine plantation pumice soils (low organic matter and organic-rich topsoil) through organic amendments (thermally dried digested/undigested biosolids and biochars, $350 / 700^{\circ} \mathrm{C}$ ). In contrast to the undigested and digested biosolids topsoil additions, which had near negligible effects on herbicide adsorption, both biochars, particularly the $700^{\circ} \mathrm{C}$ material, promoted this. Further, desorption was also resisted more strongly by the biochars than the biosolids. In conclusion, the workers suggested that through the intervention of biochar, groundwater could be protected from the hydrophobic herbicide.

The two carcinogenic herbicides atrazine and acetochlor were the focus of studies made by Spokas et al. (2009) who used Waukegan silt loam soil amended $\left(2-60 \% \mathrm{w} / \mathrm{w}, 24-720 \mathrm{t} \mathrm{ha}^{-1}\right)$ with $\mathrm{CQuest}^{\mathrm{TM}}\left(500^{\circ} \mathrm{C}\right)$ biochar to examine respiration, nitrous oxide production, methane oxidation and herbicide transformation (atrazine, $1.04 \mu \mathrm{g}$ $\mathrm{g}^{-1}$ soil; and acetochlor, $1.06 \mu \mathrm{g} \mathrm{g}^{-1}$ ) and retention (atrazine/acetochlor, 0.23-22.67 $\mu \mathrm{g} \mathrm{g}^{-1}$ soil). For all the biochar concentrations used, both $\mathrm{CO}_{2}$ and $\mathrm{N}_{2} \mathrm{O}$ productions were reduced as too was $\mathrm{CH}_{4}$ oxidation thus increasing its inimical environmental impact potential. Carbon dioxide suppression was attributed to reduced mineralization while the methane oxidation decreases were thought to be due to selective use of sorbed organic compounds. No mechanism for the $\mathrm{N}_{2} \mathrm{O}$ decreases was tendered. As anticipated by the workers, biochar addition promoted herbicide adsorption although with atrazine it had no effect with the highest initial concentration $\left(22.67 \mu \mathrm{g} \mathrm{g}^{-1}\right.$ soil). The workers compared the biochar with other types of soil organic matter and concluded that its efficacy was lower. Earlier studies by Yang and co-workers (Yang and Sheng, 2003; Sheng et al., 2005), for example, with diuron, bromoxynil and ametryne in the presence of wheat and rice biochars had recorded much higher sorption capacities. Together with sorption, herbicide bioavailability is dependent on mineralization which is 
slowed by the presence of biochar. Thus, although both leaching and runoff may be minimised by biochar application, herbicide phytotoxicity may also be reduced thus necessitating increased application.

Cao et al. (2009) also examined biochar (dairy manure, $200 / 350^{\circ} \mathrm{C}$ ) sorption of atrazine and observed that the herbicide was partitioned into its organic phase. This contrasted with their commercial activated carbon control where surface sorption was the operative mechanism.

Studies on the insecticides chlorpyrifos and carbofuran were made by Yu et al. (2009) who used Eucalyptus spp wood chips biochars $\left(450 / 850^{\circ} \mathrm{C}\right)$ to reduce the bioavailabilities of the insecticides to Spring onion (Allium cepa). Pesticide (50 mg kg${ }^{-1}$ soil) loss through degradation and/or sequestration in the sandy loam decreased as the biochar concentration $(0-1 \% \mathrm{w} / \mathrm{w}$ soil) increased although plant uptake decreased to $10 \%$ (chlorpyrifos) and $25 \%$ (carbofuran) in the presence of $1 \%$ biochar $\left(850^{\circ} \mathrm{C}\right)$ compared with the control. The workers attributed the phytoavailability reduction of both molecules to the affinity/sequestration potential of the biochar and suggested that a strategy could be developed to reduce plant uptake. In developing management practices it must be recognised, however, that biochar sorption potential can be masked by organo-mineral soil biochar interactions (Singh and Kookana, 2009).

The fungicide pyrimethanil, which inhibits methionine synthesis, was the focus of work by Yu et al. (2010) with two (450 and $\left.850^{\circ} \mathrm{C}\right)$ Eucalyptus spp biochars. In 24-hour soil equilibration tests, sorption coefficient and isotherm non-linearity both increased with biochar supplementation particularly for the higher temperature material and this was attributed to its greater surface area and microporosity.

Other organic molecules. Zhu et al. (2005) examined sorption of apolar (cyclohexane, 1,2-dichlorobenzene, 1,4xylene, 1,2,3,5-tetramethylbenzene and 1,3,5-triethylbenzene) and polar (o-cresol, 4-nitrotoluene, 2,4dinitrotoluene and 2,4,6-trinitrotoluene) molecules by five different maple (Acer sp.) wood biochars. Principal among the conclusions were: polar molecules sorbed to a higher degree than apolar compounds; the larger molecules suffered from steric exclusion; and platinum catalyst facilitated hydrogenation to remove $\mathrm{O}$ functionality promoted sorption by both molecule types by reducing competitive adsorption by water molecules.

Sorption studies of neutral organic contaminants (benzene and nitrobenzene) on two wheat (Triticum aestivum L.) biochars $\left(300 / 700^{\circ} \mathrm{C}\right)$ were reported by Chun et al. (2004). The lower temperature material was characterized by partial carbonisation, a high organic carbon content $(40-50 \%)$, reduced surface area $\left(<200 \mathrm{~m}^{2} \mathrm{~g}^{-1}\right)$ and an oxygen content $>20 \%$. In contrast, the $700^{\circ} \mathrm{C}$ product was well carbonized and had a high surface area $\left(>300 \mathrm{~m}^{2} \mathrm{~g}^{-1}\right)$ 
with low organic matter $(<3 \%)$ and oxygen $(<10 \%)$ contents. The two biochars exhibited different adsorption patterns with carbonized surface adsorption the dominant mechanism for the $700^{\circ} \mathrm{C}$ product and surface adsorption and lower partition into the residual organic matter phase operative for the lower temperature material. Both biochars exhibited higher surface affinity for the polar nitrobenzene than the non-polar benzene which they attributed to the surface acidity/basicity of the biochars.

Like Chun et al. (2004), Chen and Chen (2009) distinguished between the adsorbent carbonized organic matter and partition phase non-carbonized organic matter which, together with the surface and bulk properties, control sorption. The workers chose orange peel (cellulose, hemicelluloses and pectin) for their starter material and produced chars at nine different pyrolysis temperatures between 150 and $700^{\circ} \mathrm{C}$. After analysis (elemental, BET$\mathrm{N}_{2}$ surface area and Fourier transform infrared spectroscopy), sorption of nonpolar (naphthalene) and polar (1naphthol) hydrophobic molecules from water was used to determine the relative contributions of adsorption and partition in biochar sorption. For the pyrolysis temperature of $150^{\circ} \mathrm{C}$, the sorption isotherms for both molecules were near linear indicating the dominance of partition through the presence of an amorphous aliphatic fraction (Chen et al., 2008). With higher pyrolysis temperatures, however, the isotherm shape moved from linear to Freundlich indicating the increased contribution of adsorption, due to increased sorbent aromaticity (Chen et al., 2008), and the importance of pyrolysis temperature for bespoke biochar production. Further evidence for this isotherm shape change was reported by Chen and Yuan (2011) who examined the efficacy of pine needle biochars $\left(100,300,400\right.$ and $\left.700^{\circ} \mathrm{C}\right)$ to sorb polycyclic aromatic hydrocarbons (PAHs) and reported reduced soil supplementation requirements to achieve total sorption for the higher temperature materials.

Huang and Chen (2010) examined the sorption of polar ( $p$-nitrotoluene, $m$-dinitrobenzene and nitrobenzene) and non-polar (naphthalene) molecules to different rice straw ash charcoals, including $800^{\circ} \mathrm{C}$ biochar, and recorded comparable sorption properties, which commended the more cost-effective charcoal supplement for organic contaminant sequestration.

From this brief discussion it can be seen that a number of studies have recorded reduced mineralization of organic chemicals in soils through effective adsorption. Work by Zhang et al. (2005), however, showed that biochar nutrients, particularly phosphorus, stimulated both microbial cell growth and benzonitrile mineralization prior to catabolism slowing through adsorption. 
Together with the positive roles of biochars in promoting microbial catabolism and sequestering organic contaminants in soil, it must be recognised that they can, at times, have a negative effect. At the plant level, Yang et al. (2006), for example, found that biochar addition reduced the herbicidal effect of diuron to grass.

Metals/Metalloids. Derelict/degraded land is often characterized by a lack of top soil and, therefore, a susceptibility to improvement through, for example, compost addition. Where the land is contaminated with metals the supplementation may also result in immobilisation (Gadepalle et al., 2007) albeit on a temporary basis (van Herwijnen et al., 2007) although this could be extended by the application of biochar (Hartley et al., 2009). An alternative view is that, following carbon-rich additions, the metals/metalloids may be displaced as organic complexes (Cao et al. (2003).

Greenhouse pot trials, with three arsenic contaminated $\left(60-72 \mathrm{mg} \mathrm{kg}^{-1}\right)$ soils subjected to biochar application (20\% v/v) and planted with Miscanthus $x$ giganteus, were made by Hartley et al. (2009). In comparison to green waste compost $(30 \% \mathrm{v} / \mathrm{v})$, which improved crop yield and increased soil pore water dissolved carbon concentrations and, thus, iron and arsenic mobility, the effects of biochar were much less pronounced although increased pore water arsenic was apparent with two of the soils. The workers speculated that a rise in $\mathrm{pH}$ might have been responsible since arsenic mobility is reduced in acidic soils due to iron oxide surface adsorption (Madejón and Lepp, 2007). Also, bioavailable nutrients, such as phosphorus, as a consequence of biochar addition (Lehmann et al., 2003a), would have competed with the arsenic for binding sites.

Pot trials (60 days), complemented by Lolium perenne L. var Cadix shoot emergence testing, were also used by Beesley et al. (2010) to examine the mobility, bioavailability and toxicity of zinc, cadmium, arsenic and copper, together with PAHs, in the presence of added commercial green waste compost and hardwood biochar. For copper and arsenic, both supplementations effected $>30$-fold soil pore water increases, which were attributed to dissolved organic carbon and $\mathrm{pH}$ increases. In contrast, the zinc and cadmium concentrations both decreased with biochar proving more effective for the latter. Since, as discussed above, biochar may be used as a compost bulking agent, it may be speculated that, compared with green waste compost, this compost type could have improved efficacy to reduce the bioavailability of inorganic and PAH soil contaminants.

Studies with lead were made by Cao et al. (2009) who used dairy manure biochar $\left(200 / 350^{\circ} \mathrm{C}\right)$ to examine metal sorption. The biochar, particularly the $200^{\circ} \mathrm{C}$ material, was found to be six-times more effective than commercial activated carbon. Sorption followed a dual Langmuir-Langmuir model due to lead precipitation $\left(\beta_{-}-\mathrm{Pb}_{9}\left(\mathrm{PO}_{4}\right)_{6}\right.$, 
$\left.200^{\circ} \mathrm{C} ; \mathrm{Pb}_{3}\left(\mathrm{CO}_{3}\right)_{2}(\mathrm{OH})_{2}, 350^{\circ} \mathrm{C}\right)(84-87 \%)$ and surface sorption (13-16\%). In contrast, activated carbon sorption obeyed a single Langmuir model which the workers attributed to surface sorption. They also considered the dual sorption of lead and atrazine and recorded little competition for biochar sorption in contrast to the strong competition on activated charcoal.

\section{Soil microbial response to biochar}

The observed actions of biochar on soil microbiological activity result from at least three effects: alteration of phyico-chemical interactions, such as increased water and nutrient retention; electron donor provision; and provision of habitat.

Physico-chemical effects. The presence of biochar in soil promotes enhanced water holding capacity (Pietikäinen et al., 2000), nutrient adsorption capabilities (Dünisch et al., 2007, Major et al., 2009), dissolution-precipitation, acid-base reactions, redox reactions (Joseph et al., 2010) and cation retention (Lehmann 2007). Wardle et al. (1998) suggested that nutrient adsorption facilitated increased availability and Ortega-Calvo and Saiz-Jimenez (1998) showed that co-adsorption of substrate and microorganisms increased bioavailability.

Organic molecule sorption by biochar is a function of its aromaticity (Chen et al., 2008; Chen et al., 2009) and, hence, pyrolysis temperature (Wang et al., 2010; Yu et al., 2009) since increases lead to higher aromaticity (Brewer et al., 2009), and elevated herbicide (Wang et al., 2010) and pesticide adsorption capacity and phytoavailability (Yu et al., 2009). Although cation retention is enhanced by the presence of biochar relative to soil organic carbon, this is a poorly understood function of biochar age (Lehmann, 2007).

The potential for more subtle physico-chemical modifications of soil microbial ecology is the focus of much work. As discussed above, since flavanoid plant signals have similar adsorption properties to low molecular weight polycyclic aromatic hydrocarbons (Shaw and Hooker, 2008), it has been postulated that there may be negative effects on bioavailability of these molecules in the rhizosphere, potentially affecting interactions such as nitrogen fixation (Shaw, 2010). Furthermore, several researchers (Thies and Grossman, 2006; Thies and Rillig, 2009) observed that microbial extracellular enzymes may interact with biochar in a variety of presently poorly understood ways.

In summary, the surface properties of biochar exert positive effects on soil nutrients and cations. Co-adsorption can lead to increased local nutrient concentrations for microbial community species and enhanced water retention 
while organics adsorption leads to reduced run-off loss, although there may be competing negative effects on nutrient phytoavailability and microorganism-plant signalling arising from sorption. Although it has been shown (Durenkamp et al., 2010) that supplementation $\left(3.5 / 28 \mathrm{mg} \mathrm{C} \mathrm{g}^{-1}\right.$ soil) of silty clay loam, loamy sand and Chinese red loam with beech $\left(500^{\circ} \mathrm{C}\right)$ and maize straw/wood waste $\left(350-400^{\circ} \mathrm{C}\right)$ biochars did not decrease the fumigation extraction efficiencies of biomass carbon or biomass ninhydrin-nitrogen, sorption phenonema could have important implications for chemical extraction methodologies.

Substrate provision. Biochar, although generally perceived as an inert soil material, undergoes changes on two different timescales. Initially, residual adsorbed pyrolysis products act as substrates for soil biota and, consequently, soil microbial populations are affected by the quality of the applied material. Biochar quality, in turn, depends on feedstock and pyrolysis conditions (Zimmerman, 2010). In particular, flash- and low-temperature pyrolysis give rise to residual bio-oils and re-condensed materials (Steiner et al., 2007c). Low molecular weight oxygenated volatile organic compounds (acids, alcohols and carbonyls) serve as substrates (Steiner et al., 2007c) in low concentrations, but are toxic to microorganisms at higher concentrations (Deenik et al., 2010; Steiner et al., 2007c) as are polycyclic aromatic hydrocarbons, cresols and xylenols (Thies and Rillig, 2009). To probe recalcitrance, Hilscher and Knicker (2011) made 28-month microcosm incubation studies with ${ }^{13} \mathrm{C}$ - and ${ }^{15} \mathrm{~N}$ enriched Lolium perenne biochar $\left(350^{\circ} \mathrm{C}\right)$ in $\mathrm{Bw}$ horizon Cambisol and elucidated the humification processes at different times with solid-state ${ }^{13} \mathrm{C}$ and ${ }^{15} \mathrm{~N}$ NMR spectroscopy. Following incubation, changes were recorded in the proportion of O-containing functional groups (increased) and aryl $\mathrm{C}$ and $\mathrm{N}$-containing heterocyclic structures (both decreased) from which the workers concluded that the attendant physical and chemical property changes both made the biochar more labile and increased its adsorption capacity. Also, the degradation of N-heterocyclic domains suggested important implications for the soil nitrogen cycle.

Increased microbial biomass (Zackrisson et al., 1996) respiration and respiration efficiency (Steiner et al., 2007b) have been reported in response to biochar treatment. Studies of microbial respiration by researchers at Rothamsted, UK, for example, have shown that initial 'flushes' of $\mathrm{CO}_{2}$ evolution following biochar addition, returned to control levels after a few days (Durencamp and Brookes, 2010). Comparable studies by Smith et al. (2010a) with Panicum virgatum biochar $\left(500^{\circ} \mathrm{C}\right)$ supplementations of two silt loam soils also recorded immediate $\mathrm{CO}_{2}$ evolutions, which continued for six days, from the char in proportion to the addition. The workers concluded that the pyrolysis bio-oil condensates were the likely labile carbon pool. Supporting evidence for this was provided by Luo et al. (2010) who reported that lower temperature biochars resulted in enhanced $\mathrm{CO}_{2}$ evolution 
due to higher amounts of water-extractable organic carbon. Biochar mediated $\mathrm{CO}_{2}$ evolution must also be considered in the context of greenhouse gas emissions with reports of increased methane and decreased nitrous oxide releases from rice paddy supplemented with 10-40 $\mathrm{t} \mathrm{ha}^{-1}$ (Zhang et al., 2010).

In the long term, biochar is a recalcitrant form of carbon. A $50 \mathrm{~nm}$ spatial resolution near-edge X-ray adsorption fine structure spectroscopy (NEXAFS) map of the distribution of carbon environments in carbon particles from Amazonian Dark Earths demonstrated that surface oxidation occurs only over very long timeframes (Liang et al., 2006). Nevertheless, increases in soil microbial biomass, respiration and respiration efficiency have been reported for these (Thies and Rillig, 2009; Thies and Suzuki, 2003) relative to surrounding native soils. Furthermore, differences in soil microbial community composition, relative to similar, adjacent native soils, have been demonstrated by sequencing (O’Neill et al., 2009) and genetic fingerprinting (Grossman et al., 2010). It is apparent, therefore, that biochar addition affects microbial ecology beyond the timescale of adsorbed residuals metabolism. Presumably, adsorption processes lead to alterations in soil substrate concentration and availability over the longer term (Wardle et al., 1998). Hence, the soil microbial population, which establishes following biochar amendment varies according to biochar type (electron donors), amount, frequency of addition and age (longer term effects) (Joseph et al., 2010).

Habitat provision. Pores in biochar can provide support surfaces for microbial colonisation which, together with enhanced water holding capacity, can afford a suitable habitat for microorganisms. Pietikäinen et al. (2000) compared microbial communities of biochar and pumice supports and found that the former supported larger numbers with higher respiration rates than either pumice or activated charcoal, with relatively low and relatively high specific surface areas and adsorption capacities, respectively. These results were interpreted as evidence that elevated microbial abundance required a high surface area in combination with high water retention.

Also, the two materials supported distinct population types as demonstrated by phospholipid fatty acid analysis. These differences in microbial ecology remain unresolved although they may result from pore size variations affording protection from fungal grazers (Warnock et al., 2007), or effecting $\mathrm{pH}$ and local concentrations of pore gases (Thies and Rillig, 2009). Electron microscopy work by Luo et al. (2010) demonstrated that the pores of lower pyrolysis temperature biochars provide secure environments for microorganisms.

Discussions of soil microbial responses to biochars would be incomplete without consideration of enzyme activities. Bailey et al. (2011) examined enzyme activity (ß-glucosidase, ß-N-acetylglucosaminidase, leucine 
aminopeptidase and lipase) in the presence of Panicum virgatum biochar in three soil types (Palouse silt loam, Quincy sand and Warden sandy loam) but recorded inconsistent results with both increased (enzyme function chemical enhancement) and decreased (substrate sorption) activities apparent. Although not proven in the study, the workers speculated that enzyme activity promotion may have been due to the release of an enzyme-specific allosteric upregulator, such as ethylene, from the biochar.

\subsection{Microbiological/molecular analysis}

Although the combined and enhanced role of char and soil microbial populations in ecosystem amelioration are recognised (Glaser et al., 2002; Warnock et al., 2007), limited research has been reported of microbial diversity/functional response to the approach (Pietikäinen et al., 2000; Warnock et al., 2007; 2010); Steinbeiss et al., 2009). The distinctive physical/chemical/biological properties of biochar, including high water-holding capacity relative to activated charcoal, large internal surface area, cation exchange capacity, elemental composition and a wide range of pore size/volume/distribution (Pietikäinen et al., 2000), effect its recognised influence on microbial ecology. Thus, it adsorbs soluble organic matter/gases/inorganic nutrients, and so provides a robust habitat for diverse soil microbial associations protected from predation/desiccation (Warnock et al., 2007). Its sorptive properties can, however, lead to biases in total microbial activity assessments and these necessitate comprehensive investigation.

To date, studies of microbial community responses to biochar have relied on assays such as soil respiration $\left(\mathrm{CO}_{2}\right.$ evolution), colorimetric and fluorescent measurements, culturing, hyphal abundance, phospholipid fatty acid analysis (PLFA), restriction fragment length polymorphism (RFLP) automated ribosomal intergenic spacer analysis (ARISA) and sequencing (Kolb et al., 2009; O’Neill et al., 2009; Steinbeiss et al., 2009; Smith et al., 2010; Warnock et al., 2010; Bailey et al., 2011; Khodadad et al., 2011). An example is 16S rRNA gene analysis of pepper and tomato rhizosphere communities in the presence of biochar (Graber et al., 2010). Although the plants were grown in soilless media by fertigation - the application of water soluble products through irrigation the researchers recorded an increased abundance of culturable communities in augmented treatments with 16 of the 20 unique isolates affiliated with plant growth promoting and/or biocontrol agents. Similarly, preliminary investigations in our laboratory with denaturing gradient gel electrophoresis (DGGE) and nutrient agar (10\% strength) cultivations revealed increased numbers of colony forming units, predominance of Gram-negative rods but reduced diversity re species richness and numerical dominance in a biochar-supplemented domestic garden soil. Other researchers (Khodadad et al., 2011) have used molecular quantitative polymerase chain reaction 
(qPCR) and nested PCR-ARISA) and culture-dependent analyses to investigate the effects of two biochar types on forest soils with and without burn histories. Briefly, the high temperature biochar-supplemented soils showed peaks in viable cell counts and 16S rRNA gene copy numbers. However, despite increased rates of respiration, a general decrease in the diversity of total bacteria was observed with direct plating and qPCR showing a numerical decrease in relative abundance especially in unburnt soils augmented with a low temperature Oak250 biochar. Nonetheless, sequencing showed an increase in the relative abundance of Actinobacteria and Gemmatimonatedes. The authors concluded that their study was consistent with previous findings where biochar augmentation resulted in an enrichment of specific taxa, especially the Actinobacteria, in fire-impacted soils. Environmentally ubiquitous, particularly in soils, members of this phylum are central to organic material decomposition and humus formation (Ventura et al., 2007) and, therefore, the carbon cycle including biochar development and soil application.

A review by Nielsen et al. (2011) examined critically 26 published microbial ecology studies (reflecting 85 experimental observations) to highlight the importance of recognising the diversity-function relationship within the context of soil biodiversity and carbon cycling. They proposed that magnitudes of positive - linear, redundant/asymptotic or idiosynractic, neutral and negative effects on the cycle would be dependent on soil species richness, traits and community composition. Although made for the carbon cycle, one of their principal conclusions, that studies on general and specialized ecosystem function in relation to biodiversity in response to anthropogenic activities were essential, is also relevant to investigations on soil biochar application. Therefore, shifts in soil microbial composition, species richness and evenness, as related to key functional/process stability and attendant enzyme activity, must be determined. Consequently, Bailey et al. (2011) measured biological activity of $\beta$-glucosidase, $\beta$-N-acetylglucosaminidase, lipase, and leucine aminopeptidase to establish, generically, soil capacity to metabolise carbohydrates, lipids and proteins in the presence of biochar. They reported highly variable responses of the four enzymes in three different soils to $2 \%(\mathrm{w} / \mathrm{w})$ augmentation. Therefore, extensive proteomic investigations should provide potentially more conclusive data that complement the colorimetric and fluorescent assays, which, in this instance, showed either increased or decreased activity.

Nevertheless, obvious and considerable knowledge gaps still exist. For example, extensive research over the last two decades has established that culture-based analyses of complex ecosystems such as soils, sediments and surface-/groundwater are still limited largely to $\leq 5 \%$ of all microbial species (Amman et al., 1995; Head et al., 1998). Consequently, molecular analysis of mixed and unknown species by techniques such as DNA-/RNA-based conventional and quantitative polymerase chain reaction (PCR) (Lee et al., 1996; Bach et al., 2002; Koenigsberg 
et al., 2005), DGGE (Muyzer and Smalla, 1998), PCR-single strand conformation polymorphism (SSCP)

(Schwieger and Tebbe, 1998), fluorescent in situ hybridization (FISH), t-RFLP (Hartman and Widmer, 2008), and clone libraries has become routine. Therefore, comprehensive approaches must be taken with the analyses of total and functional microbial communities central to determining biochar impacts on specific ecosystems. For example, the expression of key catabolic genes and enzymes from known populations/genera/species can be targeted through qPCR, transcriptomics (McGrath et al., 2008; Shrestha et al., 2009; Vandenkoornhuyse et al., 2010) and (meta)proteomic analysis (Maron et al., 2007; Schneider and Riedel, 2010), while community profiling can be made with DGGE, T-RFLP, 'qfingerprinting' (Ramette, 2009) and ARISA (Danovaro et al., 2006; Kovacs et al., 2010). Increasingly, these methods are complemented by novel software applications (Yu et al., 2005; Schloss et al., 2009; Giongo et al., 2010) that have been developed specifically to process the vast data that often result from molecular microbial ecology studies of complex interacting associations. Also, as already discussed, mycorrhizas continue to be the focus on the impact of biochar on soil populations, probably because they play an important role in rhizospheric interactions. Joseph et al. (2010) presented a summary of microscopy,

chromatography and spectroscopy based studies to investigate/propose mechanisms of root growth in biocharsupplemented soils. Generally, root hairs can penetrate the water-filled macropores, influence local mineral, electron donor/acceptor and redox gradients and, consequently, affect the distribution of attendant microorganisms, including mycorrhizal fungi. Furthermore, bioturbation via biochar ingestion by soil macrofauna such as worms, termites and larvae will redistribute the material, its surface-attached communities and their inherent functional capacities especially vertically through the soil profile. The macrofauna can also have direct impacts on surface area, aeration, nutrient availability, environmental parameters such as $\mathrm{pH}$ (e.g. the termite gut is generally alkaline with $\mathrm{pH}>10$ or 12 found in some species (Brune et al., 1995; Brune and Friedrich, 2000)) and, thus, microbial occurrence/activity. Hence, although in a non-biochar study, this bioturbation phenomenon was also observed by Liu et al. (2011) where burrows of the earthworm Aporrectodea caliginosa showed increased microbial herbicide degradative enzyme activity. Generally, these physical and biochemical mechanisms create unique micro-geographical ecosystems within the soil structure. Therefore, the recent application of (macro)ecology analytical tools/indicators in molecular microecophysiology (Prosser et al., 2007), such as DGGE/T-RFLP data interpretation for taxa-area/biogeography relationships in (arbuscular) mycorrhizal fungal (van der Gast et al., 2010) and bacterial (Bell et al., 2005) populations, should facilitate the measurement of microbial spatial and temporal distribution in the presence of biochar. 
The increased application of molecular microbial ecology techniques has also led to greater awareness of both their potentials and limitations. This in turn has facilitated the improvement of existing tools and/or application of novel ones such as microarrays. Subject to successful nucleic acid recovery, these platforms, unlike their counterparts, typically circumvent PCR/amplification biases, are (semi-)quantitative, high throughput and allow simultaneous analyses of community composition, structure and function in increasingly complex ecosystems (Wu et al., 2001; Li and Liu, 2003; Zhou et al., 2010). Also, while less laborious and faster than other ecogenomic protocols, they are generally more sensitive. As a result, greater microbial diversity in urban aerosol, subsurface soil, subsurface water and spacecraft clean rooms has been recorded, for example, with phylogenetic 16S rRNA gene microarray (PhyloChip) analyses than with 'universal' (16S rRNA) and functional gene clone libraries alone (DeSantis et al., 2007; Probst et al., 2010). Similarly, the application of genechips to both pristine and contaminated environments revealed rich, diverse and robust microbial communities (He et al., 2007; Hollister et al., 2010; Xu et al., 2010). Consequently, attempts to address the recognised and new challenges of high throughput microbial ecology platforms, including competitive chemistries/hybridization, difficulties with creating and maintaining conditions that are optimum for all array probes, even detection of different signal intensities, specificity, attendant data analysis, etc. (Avarre et al., 2007; He et al., 2010) continue to be made (Liang et al., 2010; Oh et al., 2010) to facilitate wider and more comprehensive applicability. For example, combinations of genechips with other tools such as FISH have been developed and applied to monitor both bacterial and fungal populations (Metfies and Medlin, 2008). Also, although they recognized some limitations for application on high density arrays, Cao et al. (2002) and Avarre et al. (2007) recommended several improvements including the use of nanoparticles to increase hybridization specificity. However, any co-extraction of biochar particles during nucleic acid recovery, and subsequent application on nanoparticle-enhanced arrays, would possibly present interesting challenges regarding surface charge interactions. For example, any preferential/competitive binding of the biochar to the nanoparticle-probe moieties could potentially result in inhibitory binding of the environmental nucleic acids to the probes on the arrays. . Nevertheless, any improvements to these already powerful tools should, ultimately, benefit the requisite detailed and comprehensive analyses of the full impacts of contemporary biochar applications. These can be realised and exemplified during gene expression studies especially in contaminant degradation in the presence of biochar. Furthermore, differences in soil types, land use histories, application regimes and experimental designs complicate direct comparisons between (microecophysiology) investigations of contemporary soil biochar augmentation (Kolb et al., 2009). The consistent and now well established platforms such as the PhyloChip and GeoChip 2.0/3.0, and 
their demonstrable applicabilities in diverse ecosystems, will facilitate comparisons of microbial community structural and functional responses to biochar, including references to specific biogeochemical cycles/processes (C, N, metal resistance, organic contaminant remediation, etc.).

As discussed above, the results of some studies infer the need for repeat applications of biochar for sustained efficacy. The implications of this approach on the soil physical structure, mineral composition (Carson et al., 2007), microbial abundance (Warnock et al., 2010), nutrient and contaminant bioavailability, particularly in relation to biotoxicity and soil 'health' (Dawson et al., 2007; Federonkova et al., 2010), must be determined. Therefore, small bespoke microarrays could also be developed to test the biotoxicity of specific chars using single strains (Johnson et al., 2008) and/or model communities and then enriched indigenous catabolic communities.

Notwithstanding their analytical power/capacity, ecogenomic tools do not provide phenotypic or physiological characterization of novel and previously uncultivated microbial strains. This results in a discrepancy that compromises a more complete understanding of microbial diversity in specific ecosystems, particularly soil. As a result, extensive research is underway to address the well recognised limitations (Amman et al., 1995) of culturebased methods so that seemingly important community members (e.g. as identified by numerical dominance or relative abundance) or representatives of functionally significant groups can be cultivated for further analyses. Despite the debate for and against cultivation, with or without molecular analyses (Tyson and Banfield, 2005; Ritz, 2007), the approach has been exemplified by many researchers such as Bollmann et al. (2010) who used a diffusion chambers to cultivate and study the physiology of strains from acidic, heavy metal-contaminated sites. Naturally, the isolates were capable of growing in low $\mathrm{pH}$ conditions in the presence of high concentrations of nitrate and heavy metals. Subsequent 16S rRNA gene analyses showed representation of Actinobacteria, Firmicutes, Bacteroidetes and Alpha/Beta/Gamma Proteobacteria. Stevenson et al. (2004) used several strategies to mimic the soil environment including incubation atmospheres of elevated $\mathrm{CO}_{2}(5 \% \mathrm{v} / \mathrm{v})$ and $\mathrm{O}_{2}(2 \% \mathrm{v} / \mathrm{v})$ concentrations. Subsequent plate wash PCR and sequencing revealed a predominance of Acidobacteria and Verrucomicrobia in the agricultural soil and guts of wood-feeding termites. Similarly, Joseph et al. (2003) resuspended soil samples in VL55 medium (Sait et al., 2002) prior to plating on a 1/100 dilution nutrient broth and recovered 350 isolates of the subdivisions of five key phyla including Acidobacteria, Proteobacteria, Verrucomicrobia, Gemmatimonadetes and Actinobacteria. Due to the widely observed ubiquity of their 16S rRNAs or 16S rRNA genes in soils (Joseph et al., 2003; Stevenson et al., 2004), these phylogenetic groups were also recorded as indicators of soil microbial ecological response to biochar, with Verrucomicrobia (Grossman et al., 2010) and Actinobacteria (Khodadad et al., 2011), for example, showing higher relative abundances due to the 
augmentation. Therefore, culture-dependent tools/approaches, including community-level physiological profiling (Chaer et al. 2009; Bougnom et al., 2010), 'habitat' or ecological media, such as soil extract broth/agar (Liebeke et al., 2009; Bastida et al., 2010; Bučková et al., 2010), simulated natural environments and protracted incubation times (e.g. up to 12 weeks; Sait et al., 2002) will be essential for understanding the physiological responses of soil microbial communities to different biochars.

Furthermore, it is well recognised that one of the principal challenges of successful contemporary application and exploitation of biochar is understanding the attendant complex soil-microorganism-biochar interactions. As a result, the application of magnetised biochars (C-Cure Solutions Ltd., www.forestresearch.gov.uk) may be applicable in relatively simple laboratory-scale reactors with slurries and liquid cultures. Thus, the biochar can be extracted to make comparative determinations of the distribution of free-living (planktonic) and surface-attached (biofilm) microbial communities with time. The latter could then entail specific analyses of preferential attachment between the biochar and soil surfaces. This can be achieved, for example, with combinations of culture, molecular, spectroscopy, microscopy and chromatography based techniques as discussed in this and other biochar-related reviews. Also, nanoparticles have been applied increasingly in microbial ecology to exploit the potential of magnetic carrier technology for simultaneous concentration, separation/recovery and purification of biomolecules (Sebastianelli et al., 2008). This tool would, therefore, enhance the recovery of the active/growing and functional community members. These potentially powerful tools within the context of soil microbial community response to biochar could be extended with additional fundamental investigations using the thymidine analogue, bromodeoxyuridine (BrdU) (Borneman, 1999; Hamasaki et al., 2007; McMahon et al., 2010). The defining principle of the BrdU immunocapture approach - enrichment and recovery of populations that grow in response to specific stimuli and incorporate the BrdU label into de novo DNA, should facilitate analysis of the physiological response of probably the functionally significant components of the soil communities. Naturally, careful experimental design to maximize microbial community recovery and subsequent analysis must be central to studies that employ combinations of the magnetic biochar, nanoparticle and BrdU based approaches to avoid possibly competitive and/or inhibitory interactions. Nevertheless, these fundamental investigations can then be complemented by potentially more rapid and precise fingerprinting techniques such as denaturing highperformance liquid chromatography coupled with T-RFLP (Penny et al., 2010), to expediently link the physiological/phenotypic and phylogenetic characteristics of the soil populations, especially numerically and/or functionally significant members. 
The recovery, particularly from soils, of high quality, high quantity nucleic acids suitable for a variety of downstream analyses and representative of all microbial communities remains a challenge. Also, expediency through fast methods that allow rapid processing of large sample numbers is a key consideration for the development and application of efficient/robust/balanced protocols. Extensive research has been made on this fundamental step as reviewed by Schneegurt et al. (2003) and Kirk et al. (2004). A few examples of how some typical bottlenecks can be addressed have been provided by: Gabor et al. (2003), who used indirect environmental DNA extraction for subsequent gene bank construction; Kabir et al. (2003), who investigated three extraction protocols for downstream real-time quantitative PCR; Braid et al. (2003), with focus on chemical flocculation for the removal of PCR inhibitors; and Delmont et al. (2011), who compared different strategies to circumvent extraction biases while recovering currently inaccessible communities especially for metagenomic studies. For biochar, addressing these limitations was explored by Durenkamp et al. (2010), who studied the efficacy of $\mathrm{K}_{2} \mathrm{SO}_{4}$ fumigation extraction to recover microbial biomass carbon and ninhydrin-N following biochar or activated charcoal supplementation of three soil types. They found that carbon recovery was dependent on soil type, biochar and extractant concentration. Also, Grossman et al. (2010) modified the protocol of a commercial soil DNA extraction kit with an additional phenol-chloroform purification step followed by nested PCR. These steps enhanced the detection and subsequent exploration of the bacterial and archaeal diversity in Terra preta by DGGE and T-RFLP (Personal communication). Generally, different nucleic acid extraction methods have proved successful as demonstrated by application to high throughput platforms, which must be sensitive and specific, such as phylogenetic and functional microarrays. Since the addition of biochar could introduce further difficulties to the fundamental challenge of microbial surface attachment, stable isotope labelled substrates could be used in studies that combine these with respiratory measurements (Neufeld et al., 2007; Schwartz, 2007). Therefore, ${ }^{13} \mathrm{CO}_{2}$ evolution, for example, would establish the activity of the complete biome while the molecular-based analysis would reflect only the recoverable sub-communities of the biochar-augmented soil. Notwithstanding the obvious costs, bespoke radio-/stable isotope labeled chars could also be developed for definitive investigations of mass/carbon balance calculations and recalcitrance (Smith et al., 2010) in comparison to their availability as electron donors or susceptibility to re-mineralisation (Zimmerman, 2010).

The successful design and implementation of comprehensive microbial ecology investigations is underpinned increasingly by the use of toolboxes with a suite of relevant and complementary culture-/molecular-based techniques, which address the inherent limitations of each. For example, the key challenges of sample collection, handling, processing and analysis, to ensure accurate representation of the original ecosystem, can be 
circumvented with in situ methodologies. Thus, despite their well established limitations such as costs, representative/even labelling, and signal detection sensitivity against potentially competitive backgrounds, especially with real environmental samples (Neufeld and Murrell, 2007), further developments in tools that can be used for whole communities in situ or with minimal disruption ex situ, including substrate-tracking autoradiography (STAR)-FISH (Lee et al., 1999; Ouverney and Fuhrman, 1999), Raman/infrared spectroscopy (Singer et al., 2005; Harz et al., 2009), Raman-FISH (Huang et al., 2007b), and Fourier transform infrared (FTIR) spectroscopy (Wharfe et al., 2010), will be fundamental to biochar research. Also, rapid clone library management schemes (Grant and Ogilvie, 2004) and extensive metagenomic analysis with techniques such as 454-pyrosequencing (Liu et al., 2009; Rothberg and Leamon, 2008), to identify and quantify (occurrence/distribution/prevalence) species components, in the presence and absence of biochar, will be invaluable. Ultimately, the responses of total and functional microbial communities in pristine and contaminated environments will have to be determined for both different biochars and application regimes, and in relation to specific ecosystems.

\section{Summary}

The application of char to soil, as biochar, especially for increased and sustained agricultural output, was practised by ancient civilisations in different parts of the world. This practice is receiving renewed research interest, particularly for carbon sequestration, and, potentially, composting and restoration/amelioration of contaminated environments. This review, therefore, considers findings of biochar application to diverse ecosystems and in the presence of a wide range of organic and inorganic compounds such as heavy metals, pesticides, polycyclic aromatic hydrocarbons, etc. Reported and new knowledge gaps to be addressed for successful exploitation in agriculture and several environmental biotechnologies are identified. Thus, examples of specific pathways and their relevance in mycorrhizal interactions to effect increased crop yield, and phytoremediation, via phytoextraction/phytoaccumulation, are explored together with possible underpinning physical, chemical and biological mechanisms. Similarly, the potentially inhibitory effects of biochar, such as decreases in molecule bioavailability during bioremediation programmes, pesticide adsorption with reduced phytotoxicity and nutrient sequestration in agricultural soil, are discussed. The longevity of char in relation to its biodegradability and carbon and trace elements source, and as a co-metabolism substrate are additional essential considerations.

Generally, the recognised historical benefits seem to justify contemporary biochar exploitation although the mechanisms are complex and require further study. Specifically, the efficacies of different chars in different 
ecosystems are dependent on the source material, production conditions, application regimes, target molecules and site specific parameters. As a result, there is need for comprehensive and consistent/reliable tool kits to explore the attendant mechanisms from both multi-disciplinary and multi-phasic perspectives. Therefore, established/novel cutting edge tools to elucidate char physico-chemical properties prior to, during and post application to soils are considered. These should be complemented by molecular microecophysiology techniques for definitive studies of microbial community response for directed and sustainable exploitation in the different biotechnologies to then establish robust monitoring programmes. Consequently, some of the literature cited provides examples of tool kits, with protocols used to study historical biochar exploitation in, for example, Amazonian Dark Earths, thus establishing particularly relevant platforms for comparisons with new scenarios. 


\section{References}

2 Abdullah, H. \& Wu, H. (2009) Biochar as a fuel: 1. Properties and grindability of biochars produced from the pyrolysis of mallee wood under slow-heating conditions. Energy and Fuels 23, 4174-4181.

4 Abend, L. (2008) The biochar solution. Time South Pacific 49, 51.

5 Adhikari, B. K., Barrington, S., Martinez, J. \& King, S. (2009) Effectiveness of three bulking agents for food waste composting. Waste Management 29, 197-203.

7 Agblevor, F. A., Beis, S., Kim, S. S., Tarrant, R. \& Mante, N. O. (2010) Biocrude oils from the fast pyrolysis of poultry litter and hardwood. Waste Management 30, 298-307.

Allen, M.F. (2007) Mycorrhizal fungi: Highways for water and nutrients movement in arid soils. Vadose Zone Journal 6, 291-297.

Amman, R.I., Ludwig, W. \& Schleifer, K.H. (1995) Phylogenetic identification and in situ detection of individual microbial cells without cultivation. Microbiology Reviews 59, 143-169.

Antal Jr., M. J., Allen, S. G., Dai, X., Shimizu, B., Tam, M. S. \& Grønli, M. (2000) Attainment of the theoretical yield of carbon from biomass. Industrial and Engineering Chemistry Research 39, 40244031.

Asai, H., Samson, B. K., Stephan, H. M., Songyikhangsuthor, K., Homma, K., Kiyono, Y., Inoue, Y., Shiraiwa, T. \& Horie, T. (2009) Biochar amendment techniques for upland rice production in northern Laos. 1. Soil physical properties, leaf SPAD and grain yield. Field Crops Research 111, 81-84.

Atkinson, C. J., Fitzgerald, J. D. \& Hipps, N. A. (2010) Potential mechanisms for achieving agricultural benefits from biochar application to temperate soils: A review. Plant and Soil 337, 1-18.

Audet, P. \& Charest, C. (2007) Dynamics of arbuscular mycorrhizal symbiosis in heavy metal phytoremediation: Meta-analytical and conceptual perspectives. Environmental Pollution 147, 609-614. for the analysis of environmental samples. Journal of Microbiological Methods 69, 242-248. 
Ayllón, M., Aznar, M., Sánchez, J. L., Gea, G. \& Arauzo, J. (2006) Influence of temperature and heating rate on the fixed bed pyrolysis of meat and bone meal. Chemical Engineering Journal 121, 85-96.

Azcón, R., Medina, A., Roldán, A., Biró, B. \& Vivas, A. (2009) Significance of treated agrowaste residue and autochthonous inoculates (arbuscular mycorrhizal fungi and Bacillus cereus) on bacterial community structure and phytoextraction to remediate soils contaminated with heavy metals. Chemosphere 75, 327-334.

Bach, H. -J., Tomanova, J., Schloter, M. \& Munch, J. C. (2002) Enumeration of total bacteria and bacteria with genes for proteolytic activity in pure cultures and in environmental samples by quantitative PCR mediated amplification. Journal of Microbiological Methods 49, 235-245.

Bailey, V.L., Fansler, S.J., Smith, J.L. \& Bolton Jr., H. (2011) Reconciling apparent variability in effects of biochar amendment on soil enzyme activities by assay optimization. Soil Biology and Biochemistry $\mathbf{4 3}$, 296-301.

Baldock, J. A. \& Smernik, R. J. (2002) Chemical composition and bioavailability of thermally altered Pinus resinosa (red pine) wood. Organic Geochemistry 33, 1093-1109.

Bastida, F., Nicolás, C., Moreno, J. L., Hernández, T. \& García, C. (2010) Tracing changes in the microbial community of a hydrocarbon-polluted soil by culture-dependent proteomics. Pedosphere 20, 479-485.

Beesley, L., Moreno-Jiméz, E. \& Gomez-Eyles, J.L. (2010) Effects of biochar and greenwaste compost amendments on mobility, bioavailability and toxicity of inorganic and organic contaminants in a multielement polluted soil. Environmental Pollution 158, 2282-2287.

Bell, T., Ager, D., Song, J.I., Newman, J.A., Thompson, I.P., Lilley, A.K. \& van der Gast C.J. (2005) Larger islands house more bacterial taxa. Science 308, 1884-1884.

Binh, T. N. \& Marschner, P. (2005) Effect of drying and rewetting on phosphorus transformations in red brown soils with different soil organic matter content. Soil Biology and Biochemistry 37, 1573-1576. 
Bird, M. I., Ascough, P. L., Young, I. M., Wood, C. V. \& Scott, A. C. (2008) X-ray microtomographic imaging of charcoal. Journal of Archaeological Science 35, 2698-2706.

Bird, M. I., Moyo, C., Veenendaal, E. M., Lloyd, J. \& Frost, P. (1999) Stability of elemental carbon in a savanna soil. Global Biogeochemical Cycles 13, 923-932.

5

Boateng, A. A. (2007) Characterization and thermal conversion of charcoal derived from fluidized-bed fast pyrolysis oil production of switchgrass. Industrial and Engineering Chemistry Research 46, 88578862.

Boehm, H. P. (1994) Some aspects of the surface chemistry of carbon blacks and other carbons. Carbon 32, 759-769.

Bollmann, A., Palumbo, A.V., Lewis, K. \& Epstein, S.S. (2010) Isolation and physiology of bacteria from contaminated subsurface sediments. Applied and Environmental Microbiology 76, 7413-7419

Borneman, J. (1999) Culture-independent identification of microorganisms that respond to specific stimuli. Applied and Environmental Microbiology 65, 3398-3400.

Bornemann, L. C., Kookana, R. S. \& Welp, G. (2007) Differential sorption behaviour of aromatic hydrocarbons on charcoals prepared at different temperatures from grass and wood. Chemosphere 67, 1033-1042.

Bougnom, B. P., Knapp, B. A., Elhottová, D., Koubová, A., Etoa, F. X. \& Insam, H. (2010) Designer compost with biomass ashes for ameliorating acid tropical soils: Effects on the soil microbiota. Applied Soil Ecology 45, 319-324.

Braid, M.D., Daniels, L.M. \& Kitts, C.L. (2003) Removal of PCR inhibitors from soil DNA by chemical flocculation. Journal of Microbiological Methods 52, 389-393.

Brewer, C. E., Schmidt-Rohr, K., Satrio, J. A. \& Brown, R. C. (2009) Characterization of biochar from fast pyrolysis and gasification systems. Environmental Progress and Sustainable Energy 28, 386-396.

Brodowski, S., John, B., Flessa, H. \& Amelung, W. (2006) Aggregate-occluded black carbon in soil. European Journal of Soil Science 57, 539-546. 
Brown, T. R., Wright, M. M. \& Brown, R. C. (2011) Estimating profitability of two biochar production scenarios: Slow pyrolysis vs. fast pyrolysis. Biofuels, Bioproducts and Biorefining 5, 54-68.

Brown, R. A., Kercher, A. K., Nguyen, T. H., Nagle, D. C. \& Ball, W. P. (2006) Production and characterization of synthetic wood chars for use as surrogates for natural sorbents. Organic Geochemistry 37, 321-333.

Brune, A. \& Friedrich, M. (2000) Microecology of the termite gut: Structure and function on a microscale. Current Opinion in Microbiology 3, 263-269.

Brune, A., Emerson, D. \& Breznak, J.A. (1995) The termite gut microflora as an oxygen sink: Microelectrode determination of oxygen and $\mathrm{pH}$ gradients in guts of lower and higher termites. Applied and Environmental Microbiology 61, 2681-2687.

Bučková, M., Godočíková, J., Zámocký, M. \& Polek, B. (2010) Screening of bacterial isolates from polluted soils exhibiting catalase and peroxidase activity and diversity of their responses to oxidative stress. Current Microbiology 61, 241-247.

Busscher, W. J., Novak, J. M., Evans, D. E., Watts, D. W., Niandou, M. A. S. \& Ahmedna, M. (2010) Influence of pecan biochar on physical properties of a Norfolk loamy sand. Soil Science 175, 10-14.

Busse, M. D., Fiddler, G. O. \& Ratcliff, A. W. (2004) Ectomycorrhizal formation in herbicide-treated soils of differing clay and organic matter content. Water, Air, and Soil Pollution 152, 23-34.

Cao, X., Ma, L., Gao, B. \& Harris, W. (2009) Dairy-manure derived biochar effectively sorbs lead and atrazine. Environmental Science and Technology 43, 3285-3291.

Cao, X., Ma, L. Q. \& Shiralipour, A. (2003) Effects of compost and phosphate amendments on arsenic mobility in soils and arsenic uptake by the hyperaccumulator, Pteris vittata L. Environmental Pollution 126, $157-167$.

Cao, Y. C., Jin, R. \& Mirkin, C. A. (2002) Nanoparticles with spectroscopic fingerprints for DNA and RNA detection. Science 297, 1536-1540. 

causes a shift in microbial community structure. FEMS Microbiology Ecology 61, 414-423.

Chaer, G. M., Fernandes, M. F., Myrold, D. D. \& Bottomley, P. J. (2009) Shifts in microbial community composition and physiological profiles across a gradient of induced soil degradation. Soil Science Society of America Journal 73, 1327-1334.

Chan, K.Y., van Zwieten, L., Meszaros, I., Downie, A. \& Joseph, S. (2007a) Agronomic values of green waste biochar as a soil amendment. Australian Journal of Soil Research 45, 629-634.

Chan, K. Y., van Zwieten, L., Meszaros, I., Downie, A. \& Joseph, S. (2007b) Assessing the agronomic values of contrasting char materials on Australian hardsetting soil. Proceedings of the Conference of the International Agrichar Initiative, 30 April - 2 May 2007. Terrigal, NSW, Australia.

Chan, K. Y., van Zwieten, L., Meszaros, I., Downie, A. \& Joseph, S. (2008) Using poultry litter biochars as soil amendments. Australian Journal of Soil Research 46, 437-444.

Chen, B. \& Chen, Z. (2009) Sorption of naphthalene and 1-naphthol by biochars of orange peels with different pyrolytic temperatures. Chemosphere 76, 127-133.

Chen, B. \& Yuan, M. (2011) Enhanced sorption of polycyclic aromatic hydrocarbons by soil amended with biochar. Journal of Soils and Sediments 11, 62-71.

Chen, B., Zhou, D. \& Zhu, L. (2008) Transitional adsorption and partition of nonpolar and polar aromatic contaminants by biochars of pine needles with different pyrolytic temperatures. Environmental Science and Technology 42, 5137-5143.

Chen, M. -M., Chen, B. -D., Xu, Y., Tian, H. -Y. \& Deng, H. (2009) Mycorrhizal fungi in bioremediation of petroleum-contaminated soil; A review. Chinese Journal of Ecology 28, 1171-1177.

Chen, R., Lin, X., Yin, R. \& Shi, Y. (2005a) Effect of mycorrhizae on bioremediation of soils polluted by organic matters. Chinese Journal of Ecology 24, 176-180. 
Cheng, C. -H., Lehmann, J. \& Engelhard, M. H. (2008) Natural oxidation of black carbon in soils: Changes in molecular form and surface charge along a climosequence. Geochimica et Cosmochimica Acta $\mathbf{7 2}$, $1598-1610$.

Cheng, C. -H., Lehmann, J., Thies, J. E., Burton, S. D. \& Engelhard, M. H. (2006) Oxidation of black carbon by biotic and abiotic processes. Organic Geochemistry 37, 1477-1488.

Chun, Y., Sheng, G., Chiou, G. T. \& Xing, B. (2004) Compositions and sorptive properties of crop residuederived chars. Environmental Science and Technology 38, 4649-4655.

Cohen-Ofri, H., Popovitz-Biro, R. \& Weiner, S. (2007) Structural characterization of modern and fossilized charcoal produced in natural fires as determined by using electron energy loss spectroscopy. Chemistry - A European Journal 13, 2306-2310.

Cui, X., Wang, H., Lou, L., Chen, Y., Yu, Y., Shi, J., Xu, L. \& Khan, M. I. (2009) Sorption and genotoxicity of sediment-associated pentachlorophenol and pyrene influenced by crop residue ash. Journal of Soils and Sediments 9, 604-612.

Danovaro, R., Luna, G. M., Dell'Anno, A. \& Pietrangeli, B. (2006) Comparison of two fingerprinting techniques, terminal restriction fragment length polymorphism and automated ribosomal intergenic spacer analysis, for determination of bacterial diversity in aquatic environments. Applied and Environmental Microbiology 72, 5982-5989.

Dawson, J. J. C., Godsiffe, E. J., Thompson, I. P., Ralebitso-Senior, T. K., Killham, K. S. \& Paton, G. I. (2007) Application of biological indicators to assess recovery of hydrocarbon impacted soils. Soil Biology and Biochemistry 39, 164-177.

Delmont, T.O., Robe, P., Cecillon, S., Clark, I.M., Constancias, F., Simonet, P., Hirsch, P.R \& Vogel, T.M. (2011) Accessing the soil metagenome for studies of microbial diversity. Applied and Environmental Microbiology 77, 1315-1324.

De Paula, A. M., Soares, C. R. F. S. \& Siqueira, J. O. (2006) Biomass, microbial activity and mycorrhizal fungi in landfarming soil of petrochemical wastes. Revista Brasileira De Engenharia Agricola e Ambiental 10, 448-455. 
Deenik, J. L., McClellan, T., Uehara, G., Antal Jr., M. J. \& Sonia, C. (2010) Charcoal volatile matter content influences plant growth and soil nitrogen transformations. Soil Science Society of America Journal 74, $1259-1270$.

DeLuca, T.H., MacKenzie, M.D., Gundale, M.J. \& Holben, W.E. (2006) Wild-fire produced charcoal directly influences nitrogen cycling in ponderosa pine forests. Soil Science Society of America Journal 70, $448-453$.

Denef, K., Six, J., Bossuyt, H., Frey, S. D., Elliott, E. T., Merckx, R. \& Paustian, K. (2001) Influence of drywet cycles on the interrelationship between aggregate, particulate organic matter, and microbial community dynamics. Soil Biology and Biochemistry 33, 1599-1611.

DeSantis, T. Z., Brodie, E. L., Moberg, J. P., Zubieta, I. X., Piceno, Y. M. \& Andersen, G. L. (2007) Highdensity universal $16 \mathrm{~S}$ rRNA microarray analysis reveals broader diversity than typical clone library when sampling the environment. Microbial Ecology 53, 371-383.

Dias, B. O., Silva, C. A., Higashikawa, F. S., Roig, A. \& Sánchez-Monedero, M. A. (2010) Use of biochar as bulking agent for the composting of poultry manure: Effect on organic matter degradation and humification. Bioresource Technology 101, 1239-1246.

Dittmann, J., Heyser, W. \& Bücking, H. (2002) Biodegradation of aromatic compounds by white rot and ectomycorrhizal fungal species and the accumulation of chlorinated benzoic acid in ectomycorrhizal

Dover, M. (2007) Anyone for char? Dark earth holds carbon storage hope. Inwood Magazine 77, 33-34.

Downie, A. E., van Zwieten, L., Smernik, R. J., Morris, S. \& Munroe, P. R. (2011) Terra preta Australis: Reassessing the carbon storage capacity of temperate soils. Agriculture, Ecosystems and Environment, in press.

Dünisch, O., Lima, V. C., Seehann, G., Donath, J., Montóia, V. R. \& Schwarz, T. (2007) Retention properties of wood residues and their potential for soil amelioration. Wood Science and Technology 41, 169-189. 
Dupré de Boulois, H., Joner, E. J., Leyval, C., Jakobsen, I., Chen, B. D., Roos, P., Thiry, Y., Rufyikiri, G., Delvaux, B. \& Declerck, S. (2008a) Impact of arbuscular mycorrhizal fungi on uranium accumulation by plants. Journal of Environmental Radioactivity 99, 775-784.

Dupré de Boulois, H., Joner, E. J., Leyval, C., Jakobsen, I., Chen, B. D., Roos, P., Thiry, Y., Rufyikiri, G., Delvaux, B. \& Declerck, S. (2008b) Role and influence of mycorrhizal fungi on radiocesium accumulation by plants. Journal of Environmental Radioactivity 99, 785-800.

Durenkamp, M. \& Brookes, P. (2010) Impact of biochar and substrate addition on soil microbial biomass. Proceedings of the UKBRC, Rothamsted, UK, available online: http://www.geos.ed.ac.uk/sccs/biochar/Rothamsted (accessed 12/5/2010).

Durenkamp, M., Luo, Y. \& Brookes, P.C. (2010) Impact of black carbon addition to soil on the determination of soil microbial biomass by fumigation extraction. Soil Biology and Biochemistry $\mathbf{4 2}$, 2026-2029.

Ekschmitt, K., Kandeler, E., Poll, C., Brune, A., Buscot, F., Friedrich, M., Gleixner, G., Hartmann, A., Kästner, M., Marhan, S., Miltner, A., Scheu, S. \& Wolters, V. (2008) Soil-carbon preservation through habitat constraints and biological limitations on decomposer activity. Journal of Plant Nutrition and Soil Science 171, 27-35.

Elad, Y., David, D.R., Harel, Y.M., Borenshtein, M., Kalifa, H.B., Silber, A. \& Graber, E.R. (2010) Induction of systemic resistance in plants by biochar, a soil-applied carbon sequestering agent. Disease Control and Pest Management 100, 913-921.

Fedorenkova, A., Vonk, J. A., Lenders, H. J. R., Ouborg, N. J., Breure, A. M. \& Hendriks, A. J. (2010) Ecotoxicogenomics: Bridging the gap between genes and populations. Environmental Science and Technology 44, 4328-4333.

Fowles, M. (2007) Black carbon sequestration as an alternative to bioenergy. Biomass and Bioenergy 31, $426-432$.

Fuertes, A. B., Arbestain, M. C., Sevilla, M., Maclá-Agulló, J. A., Fiol, S., López, R., Smernik, R. J., Aitkenhead, W. P., Arce, F. \& Maclas, F. (2010) Chemical and structural properties of carbonaceous 
products obtained by pyrolysis and hydrothermal carbonisation of corn stover. Australian Journal of Soil Research 48, 618-626.

Gabor, E.M., de Vries, E.J. \& Janssen, D.B. (2003) Efficient recovery of environmental DNA for expression cloning by indirect extraction methods. FEMS Microbiology Ecology 44, 153-163.

5 Gadepalle, V. P., Ouki, S. K., Van Herwijnen, R. \& Hutchings, T. (2007) Immobilization of heavy metals in soil using natural and waste materials for vegetation establishment on contaminated sites. Soil and Sediment Contamination 16, 233-251.

Garcia-Montiel, D.C., Neill, C., Melillo, J., Thomas, S., Stuedler, P.A. \& Cerri, C.C. (2000) Soil phosphorus transformations following forest clearing for pasture in the Brazilian Amazon. Soil Science Society of America Journal 64, 1792-1804.

Gardner, J. H. \& Malajczuk, N. (1988) Recolonisation of rehabilitated bauxite mine sites in Western Australia by mycorrhizal fungi. Forest Ecology and Management 24, 27-42.

Gaskin, J. W., Steiner, C., Harris, K., Das, K. C. \& Bibens, B. (2008) Effect of low-temperature pyrolysis conditions on biochar for agricultural use. Transactions of the ASABE 51, 2061-2069.

Gathorne-Hardy, A., Knight, J. \& Woods, J. (2008) The use of bio-char to reduce summer water stress in cereal crops. Aspects of Applied Biology 88, 57-58.

Gell, K., van Groenigen, J. and Cayuela, M. L. (2011) Residues of bioenergy production chains as soil amendments: Immediate and temporal phytotoxicity. Journal of Hazardous Materials, in press.

Gerçel, H. F. (2002) The production and evaluation of bio-oils from the pyrolysis of sunflower-oil cake. Biomass and Bioenergy 23, 307-314.

Giongo, A., Crabb, D.B., Davis-Richardson, A.G., Chauliac, D., Mobberley, J.M., Gano, K.A., Mukherjee, 
Glaser, B., Guggenberger, G., Zech, W. \& Ruivo, M.L. (2003) Soil organic matter stability in amazonian dark earths. In Lehmann, J., Kern, D.C., Glaser, B. \& Woods, W.I. (eds) Amazonian dark earths: Origin, properties, management. Kluwer Academic Publishers, Dordrecht, pp. 141-158.

Glaser, B., Lehmann, J. \& Zech, W. (2002) Ameliorating physical and chemical properties of highly weathered soils in the tropics with bio-char - a review. Biology and Fertility of Soils 35, 219-230.

Glaser, B. (2007) Prehistorically modified soils of central amazonia: A model for sustainable agriculture in the twenty-first century. Philosophical Transactions of the Royal Society B: Biological Sciences 362 , 187-196.

González-Chávez, M. C., Carrillo-González, R. \& Gutiérrez-Castorena, M. C. (2009) Natural attenuation in a slag heap contaminated with cadmium: The role of plants and arbuscular mycorrhizal fungi. Journal of Hazardous Materials 161, 1288-1298.

Gordon, H., Haygarth, P. M. \& Bardgett, R. D. (2008) Drying and rewetting effects on soil microbial community composition and nutrient leaching. Soil Biology and Biochemistry 40, 302-311.

Goyal, S., Dhull, S. K. \& Kapoor, K. K. (2005) Chemical and biological changes during composting of different organic wastes and assessment of compost maturity. Bioresource Technology 96, 1584-1591.

Graber, E.R., Harel, Y.M., Kolton, M., Cytryn, E., Silber, A., David, D.R., Tsechansky, L., Borenshtein, M. \& Elad, Y. (2010) Biochar impact on development and productivity of pepper and tomato grown in fertigated soilless media. Plant and Soil 337, 481-496.

Grant, A. \& Ogilvie, L. A. (2004) Name that microbe: Rapid identification of taxa responsible for individual fragments in fingerprints of microbial community structure. Molecular Ecology Notes 4, 133-136.

Grierson, S., Strezov, V., Ellem, G., Mcgregor, R. \& Herbertson, J. (2009) Thermal characterisation of microalgae under slow pyrolysis conditions. Journal of Analytical and Applied Pyrolysis 85, 118-123.

Grossman, J. M., O'Neill, B. E., Tsai, S. M., Liang, B., Neves, E., Lehmann, J. \& Thies, J. E. (2010) Amazonian anthrosols support similar microbial communities that differ distinctly from those extant in adjacent, unmodified soils of the same mineralogy. Microbial Ecology 60, 192-205. 
Gundale, M. J. \& DeLuca, T. H. (2006) Temperature and source material influence ecological attributes of ponderosa pine and douglas-fir charcoal. Forest Ecology and Management 231, 86-93.

3 Gunderson, J. J., Knight, J. D. \& Van Rees, K. C. J. (2007) Impact of ectomycorrhizal colonization of hybrid poplar on the remediation of diesel-contaminated soil. Journal of Environmental Quality 36, 927-934.

5 Hamasaki, K., Taniguchi, A., Tada, Y., Long, R. A. \& Azam, F. (2007) Actively growing bacteria in the inland sea of Japan, identified by combined bromodeoxyuridine immunocapture and denaturing gradient gel electrophoresis. Applied and Environmental Microbiology 73, 2787-2798.

Hamer, U., Marschner, B., Brodowski, S. \& Amelung, W. (2004) Interactive priming of black carbon and glucose mineralisation. Organic Geochemistry 35, 823-830.

Harrison, M. J. (2005) Signaling in the arbuscular mycorrhizal symbiosis. Annual Review of Microbiology 59, $19-42$.

Hartley, W., Dickinson, N. M., Riby, P. \& Lepp, N. W. (2009) Arsenic mobility in brownfield soils amended with green waste compost or biochar and planted with miscanthus. Environmental Pollution 157, 26542662.

Hartmann, M. \& Widmer, F. (2008) Reliability for detecting composition and changes of microbial communities by t-RFLP genetic profiling. FEMS Microbiology Ecology 63, 249-260.

Harz, M., Rösch, P. \& Popp, J. (2009) Vibrational spectroscopy-A powerful tool for the rapid identification of microbial cells at the single-cell level. Cytometry Part A 75, 104-113.

Haynes, R. J. (2009) Reclamation and revegetation of fly ash disposal sites - challenges and research needs. Journal of Environmental Management 90, 43-53.

21 He, Z., Deng., Y., Van Nostrand, J.D., Tu, Q., Xu, M., Hemme, C.L., Li, X., Wu, L., Gentry, T.J., Yin, Y., 22 Liebich, J., Hazen, T.C. \& Zhou, J. (2010) GeoChip 3.0 as a high-throughput tool for analyzing microbial community composition, structure and functional activity. International Society for Microbial Ecology Journal 4, 1167-1179. 
He, Z., Gentry, T.J., Schadt, C.W., Wu, L., Liebich, J., Chong, S.C., Huang, Z., Wu, W., Gu, B., Jardine, P., Criddle, C. \& Zhou, J. (2007) GeoChip: A comprehensive microarray for investigating biogeochemical, ecological and environmental processes. ISME Journal 1, 67-77.

Head, I. M., Saunders, J. R. \& Pickup, R. W. (1998) Microbial evolution, diversity, and ecology: A decade of ribosomal RNA analysis of uncultivated microorganisms. Microbial Ecology 35, 1-21.

Herrmann, S., Oelmüller, R. \& Buscot, F. (2004) Manipulation of the onset of ectomycorrhiza formation by indole-3-acetic acid, activated charcoal or relative humidity in the association between oak microcuttings and Piloderma croceum: Influence on plant development and photosynthesis. Journal of Plant Physiology 161, 509-517.

Hilscher, A. \& Knicker, H. (2011) Carbon and nitrogen degradation on molecular scale of grass-derived pyrogenic organic material during 28 months of incubation in soil. Soil Biology \& Biochemistry 43, 261-270.

Hockaday, W. C., Grannas, A. M., Kim, S. \& Hatcher, P. G. (2007) The transformation and mobility of charcoal in a fire-impacted watershed. Geochimica et Cosmochimica Acta 71, 3432-3445.

Hoitink, H.A.J. (1993) Introduction. In Hoitink, H.A.J. \& Keener, H.M. (eds) Science and engineering of composting: Design, environmental, microbiological and utilization aspects. Renaissance Publications, Worthington.

Hollister, E. B., Schadt, C. W., Palumbo, A. V., James Ansley, R. \& Boutton, T. W. (2010) Structural and functional diversity of soil bacterial and fungal communities following woody plant encroachment in the southern Great Plains. Soil Biology and Biochemistry 42, 1816-1824.

Hossain, M. K., Strezov, V., Chan, K. Y., Ziolkowski, A. \& Nelson, P. F. (2011) Influence of pyrolysis temperature on production and nutrient properties of wastewater sludge biochar. Journal of Environmental Management 92, 223-228.

Hossain, M. K., Strezov, V., Yin Chan, K. \& Nelson, P. F. (2010) Agronomic properties of wastewater sludge biochar and bioavailability of metals in production of cherry tomato (Lycopersicon esculentum). Chemosphere 78, 1167-1171. 
Hu, Z. -Q., Yang, X. -H., Gao, A. -L. \& Wei, X. -F. (2007) Remediation of mycorrhiza on Cd contaminated soil. Zhongguo Kuangye Daxue Xuebao/Journal of China University of Mining and Technology 36, 237-240.

Hua, L., Wu, W., Liu, Y., McBride, M. B. \& Chen, Y. (2009) Reduction of nitrogen loss and Cu and Zn mobility during sludge composting with bamboo charcoal amendment. Environmental Science and Pollution Research 16, 1-9.

7 Huag, R. T. (1993) The practical handbook of composting engineering. CRC Press, Boca Raton.

8 Huang, H., Zhang, S., Shan, X. -Q., Chen, B. -D., Zhu, Y. -G. \& Bell, J. N. B. (2007a) Effect of arbuscular mycorrhizal fungus (Glomus caledonium) on the accumulation and metabolism of atrazine in maize (Zea mays L.) and atrazine dissipation in soil. Environmental Pollution 146, 452-457.

Huang, W. \& Chen, B. (2010) Interaction mechanisms or organic contaminants with burned straw ash charcoal. Journal of Environmental Sciences 22, 1586-1594.

Huang, W. E., Stoecker, K., Griffiths, R., Newbold, L., Daims, H., Whiteley, A. S. \& Wagner, M. (2007b) Raman-FISH: Combining stable-isotope spectroscopy and fluorescence in situ hybridization for the single cell analysis of identity and function. Environmental Microbiology 9, 1878-1889.

Huang, Y., Chen, Y. \& Tao, S. (2000) Effect of rhizospheric environment of VA-mycorrhizal plants on forms of $\mathrm{Cu}, \mathrm{Zn}, \mathrm{Pb}$ and $\mathrm{Cd}$ in polluted soil. Chinese Journal of Applied Ecology 11, 431-434.

Ishii, T. \& Kadoya, K. (1994) Effects of charcoal as a soil conditioner on citrus growth and vesiculararbuscular mycorrhizal development. Journal of the Japanese Society for Horticultural Science 63, $529-535$.

Iswaran, V., Jauhri, K. S. \& Sen, A. (1980) Effect of charcoal, coal and peat on the yield of moong, soybean and pea. Soil Biology and Biochemistry 12, 191-192.

James, G., Sabatini, D. A., Chiou, C. T., Rutherford, D., Scott, A. C. \& Karapanagioti, H. K. (2005) Evaluating phenanthrene sorption on various wood chars. Water Research 39, 549-558. 
Jankong, P. \& Visoottiviseth, P. (2008) Effects of arbuscular mycorrhizal inoculation on plants growing on arsenic contaminated soil. Chemosphere 72, 1092-1097.

Janoušková, M., Pavlíková, D. \& Vosátka, M. (2006) Potential contribution of arbuscular mycorrhiza to cadmium immobilisation in soil. Chemosphere 65, 1959-1965.

Johnson, D. R., Brodie, E. L., Hubbard, A. E., Andersen, G. L., Zinder, S. H. \& Alvarez-Cohen, L. (2008) Temporal transcriptomic microarray analysis of "Dehalococcoides ethenogenes" strain 195 during the transition into stationary phase. Applied and Environmental Microbiology 74, 2864-2872.

Joner, E. J., Johansen, A., Loibner, A. P., Cruz, M. A. D., Szolar, O. H. J., Portal, J. -M. \& Leyval, C. (2001) Rhizosphere effects on microbial community structure and dissipation and toxicity of polycyclic aromatic hydrocarbons (PAHs) in spiked soil. Environmental Science and Technology 35, 2773-2777.

Joner, E. J. \& Leyval, C. (2003) Rhizosphere gradients of polycyclic aromatic hydrocarbon (PAH) dissipation in two industrial soils and the impact of arbuscular mycorrhiza. Environmental Science and Technology 37, 2371-2375.

Joseph, S.D., Camps-Arbestain, M., Lin, Y., Munroe, P., Chia, C.H., Hook, J., van Zwieten, L., Kimber, S., Cowie, A., Singh, B.P., Lehmann, J., Foidl, N., Smernik, R.J. \& Amonette, J.E. (2010) An

Joseph, S., Peacock, C., Lehmann, J. \& Munroe, P. (2009) Developing a biochar classification and test methods. In Lehmann, J. \& Joseph, S. (eds), Biochar for environmental management,Earthscan, UK, pp. 107-126.

Joseph, S.J., Hugenholtz, P., Sangwan, P., Osborne, C.A. \& Janssen P.H. (2003) Laboratory cultivation of widespread and previously uncultured soil bacteria. Applied and Environmental Microbiology 69,

Juwarkar, A. A. \& Jambhulkar, H. P. (2008) Restoration of fly ash dump through biological interventions. 
Kabir, S., Rajendran, N., Amemiya, T. \& Itho, K. (2003) Real-time quantitative PCR assay on bacterial DNA: In a model soil system and environmental samples. Journal of General Applied Microbiology 49, 101-109.

Karaosmanoğlu, F., Işigigür-Ergüdenler, A. \& Sever, A. (2000) Biochar from the straw-stalk of rapeseed plant. Energy and Fuels 14, 336-339.

Katyal, S., Thambimuthu, K. \& Valix, M. (2003) Carbonisation of bagasse in a fixed bed reactor: Influence of process variables on char yield and characteristics. Renewable Energy 28, 713-725.

Kendrick, B. and Berch, S. (1984) Mycorrhizae: Applications in agriculture and forestry. In Robinson, C.W. (ed.) Comprehensive biotechnology and bioengineering. Pergamon Press, Oxford, pp. 110-152.

Khalvati, M., Bartha, B., Dupigny, A. \& Schröder, P. (2010) Arbuscular mycorrhizal association is beneficial for growth and detoxification of xenobiotics of barley under drought stress. Journal of Soils and Sediments 10, 54-64.

Khan, A. G. (2001) Relationships between chromium biomagnification ratio, accumulation factor, and mycorrhizae in plants growing on tannery effluent-polluted soil. Environment International 26, 417423.

16

Khodadad, C.L.M., Zimmerman, A.R., Green, S.J., Uthandi, S. \& Foster, J.S. (2011) Taxa-specific changes in soil microbial community composition induced by pyrogenic carbon amendments. Soil Biology and Biochemistry 43, 385-392.

Kimetu, J. M., Lehmann, J., Ngoze, S. O., Mugendi, D. N., Kinyangi, J. M., Riha, S., Verchot, L., Recha, J. W. \& Pell, A. N. (2008) Reversibility of soil productivity decline with organic matter of differing quality along a degradation gradient. Ecosystems 11, 726-739.

Kimetu, J. M. and Lehmann, J. (2010) Stability and stabilisation of biochar and green manure in soil with different organic carbon contents. Australian Journal of Soil Research 48, 577-585.

Kirk, J.L., Beaudette, LA., Hart, M., Moutoglis, P., Kliromonos, J.N., Lee, H. \& Trevors, J.T. (2004) Methods of studying soil microbial diversity. Journal of Microbiological Methods 58, 169-188 

perspective. Remediation Journal 15, 5-25.

3 Korade, D. L. \& Fulekar, M. H. (2009) Rhizosphere remediation of chlorpyrifos in mycorrhizospheric soil using ryegrass. Journal of Hazardous Materials 172, 1344-1350.

5 Kothamasi, D., Kothamasi, S., Bhattacharyya, A., Kuhad, R. C. \& Babu, C. R. (2006) Arbuscular mycorrhizae and phosphate solubilising bacteria of the rhizosphere of the mangrove ecosystem of great Nicobar Island, India. Biology and Fertility of Soils 42, 358-361.

Kovacs, A., Yacoby, K. \& Gophna, U. (2010) A systematic assessment of automated ribosomal intergenic spacer analysis (ARISA) as a tool for estimating bacterial richness. Research in Microbiology 161, 192-197.

Krpata, D., Fitz, W., Peintner, U., Langer, I. \& Schweiger, P. (2009) Bioconcentration of zinc and cadmium in ectomycorrhizal fungi and associated aspen trees as affected by level of pollution. Environmental Pollution 157, 280-286.

Krull, E. S., Skjemstad, J. O., Graetz, D., Grice, K., Dunning, W., Cook, G. \& Parr, J. F. (2003) ${ }^{13}$ C-depleted charcoal from C4 grasses and the role of occluded carbon in phytoliths. Organic Geochemistry 34, $1337-1352$.

Kuzyakov, Y., Subbotina, I., Chen, H., Bogomolova, I. \& Xu, X. (2009) Black carbon decomposition and incorporation into soil microbial biomass estimated by ${ }^{14} \mathrm{C}$ labeling. Soil Biology and Biochemistry 41 , 210-219.

Kwon, S. \& Pignatello, J. J. (2005) Effect of natural organic substances on the surface and adsorptive properties of environmental black carbon (char): Pseudo pore blockage by model lipid components and its implications for $\mathrm{N}_{2}$-probed surface properties of natural sorbents. Environmental Science and Technology 39, 7932-7939. Science 60, 158-169. 
Lebeau, T., Braud, A. \& Jézéquel, K. (2008) Performance of bioaugmentation-assisted phytoextraction applied to metal contaminated soils: A review. Environmental Pollution 153, 497-522.

Lee, J. W., Hawkins, B., Day, D., M. and Reicosky, D. C. (2010) Sustainability: the capacity of smokeless pyrolysis for energy production, global carbon capture and sequestration. Energy and Environmental Science 3, 1695-1705.

Lee, N., Nielsen, P. H., Andreasen, K. H., Juretschko, S., Nielsen, J. L., Schleifer, K. -H. \& Wagner, M. (1999) Combination of fluorescent in situ hybridization and microautoradiography - A new tool for structure-function analyses in microbial ecology. Applied and Environmental Microbiology 65, 12891297.

Lee, S. -Y., Bollinger, J., Bezdicek, D. \& Ogram, A. (1996) Estimation of the abundance of an uncultured soil bacterial strain by a competitive quantitative PCR method. Applied and Environmental Microbiology 62, 3787-3793.

Lehmann, J. (2007) Bio-energy in the black. Frontiers in Ecology and the Environment 5, 381-387.

Lehmann, J., Czimczik, C., Laird, D. \& Sohi, S., 2009. Stability of biochar in the soil. In: Lehmann, J. \& Joseph, S. (eds),Biochar for environmental management. Earthscan, London, pp. 183-206.

Lehmann, J., Da Silva, J. P., Steiner, C., Nehls, T., Zech, W. \& and Glaser, B. (2003a) Nutrient availability and leaching in an archaeological anthrasol and ferralsol of the central Amazon basin: Fertilizer, manure and charcoal amendments. Plant and Soil 249, 343-357.

Lehmann, J., Kern, D., German, L., McCann, J., Martins, G.C. \& Moreira, L. (2003b) Soil fertility and production potential. In Lehmann, J., Kern, D., Glaser, B. \& Woods, W.I. (eds) Amazonian dark earths: Origin, properties, management. Kluwer Academic, Dordrecht, pp. 105-124.

Lehmann, J. and Sohi, S. (2008) Comment on "Fire-derived charcoal causes loss of forest humus". Science 321, 1295.

Lei, H., Ren, S. \& Julson, J. (2009) The effects of reaction temperature and time and particle size of corn stover on microwave pyrolysis. Energy and Fuels 23, 3254-3261. 
1 Li, Q., Ling, W., Gao, Y., Li, F. \& Xiong, W. (2006) Arbuscular mycorrhizal bioremediation and its mechanisms of organic pollutants-contaminated soils. Chinese Journal of Applied Ecology 17, $2217-$ 2221.

4 Li, E.S.Y. \& Liu, W.-T. (2003). DNA microarray technology in microbial ecology studies - Principle, applications and current limitations. Microbes and Environments 18, 175-187.

6 Liang, B., Lehmann, J., Solomon, D., Kinyangi, J., Grossman, J., O'Neill, B., Skjemstad, J.O., Thies, J., Luizão, F.J., Petersen, J. \& Neves, E.G. (2006) Black carbon increases cation exchange capacity in soils. Soil Science Society of America Journal 70, 1719-1730.

Liang, Y., He, Z., Wu, L., Deng, Y., Li, G. \& Zhou, J. (2010) Development of a common oligonucleotide reference standard for microarray data normalization and comparison across different microbial communities. Applied and Environmental Microbiology 76, 1088-1094.

Liebeke, M., Brözel, V. S., Hecker, M. \& Lalk, M. (2009) Chemical characterization of soil extract as growth media for the ecophysiological study of bacteria. Applied Microbiology and Biotechnology 83, 161-173.

Liiri, M., Ilmarinen, K. \& Setälä, H. (2007) Variable impacts of enchytraeid worms and ectomycorrhizal fungi on plant growth in raw humus soil treated with wood ash. Applied Soil Ecology 35, 174-183.

Lin, X., Li, P., Tai, P., Gong, Z. \& Zhang, H. (2006) Research progress in phyto-microbial remediation of petroleum-contaminated soil. Chinese Journal of Ecology 25, 93-100.

Liu, Y.-J., Zaprasis, A., Liu, S.-J., Drake, H.L. \& Horn, M.A. (2011) The earthworm Aporrectodea caliginosa stimulates abundance and activity of phenoxyalkanoic acid herbicide degraders. International Society for Microbial Ecology Journal 5, 473-485.

Liu, Y. -X., Liu, W., Wu, W. -X., Zhong, Z. -K. \& Chen, Y. -X. (2009) Environmental behavior and effect of biomass-derived black carbon in soil: A review. Chinese Journal of Applied Ecology 20, 977-982. 
Lohmann, R., McFarlane, J. K. \& Gschwend, P. M. (2005) Importance of black carbon to sorption of native PAHs, PCBs, and PCDDs in Boston and New York harbour sediments. Environmental Science and Technology 39, 141-148.

Lou, L., Wu, B., Wang, L., Luo, L., Xu, X., Hou, J., Xun, B., Hu, B. \& Chen, Y. (2011) Sorption and ecotoxicity of pentachlorophenol polluted sediment amended with rice-straw derived biochar. Bioresource Technology 102, 4036-4041.

7 Lua, A. C., Yang, T. \& Guo, J. (2004) Effects of pyrolysis conditions on the properties of activated carbons prepared from pistachio-nut shells. Journal of Analytical and Applied Pyrolysis 72, 279-287.

Luo, Y., Devonshire, J. \& Brookes, P. (2010) Impact of biochar on soil microbial biomass and its mechanisms. Proceedings of the UKBRC, Rothamsted, UK, available online: http://www.geos.ed.ac.uk/sccs/biochar/Rothamsted (accessed 12/5/2010).

Madejón, P. \& Lepp, N. W. (2007) Arsenic in soils and plants of woodland regenerated on an arseniccontaminated substrate: A sustainable natural remediation? Science of the Total Environment 379, 256262.

Mahinpey, N., Murugan, P., Mani, T. \& Raina, R. (2009) Analysis of bio-oil, biogas, and biochar from pressurized pyrolysis of wheat straw using a tubular reactor. Energy and Fuels 23, 2736-2742.

Mahmood, S., Finlay, R.D., Fransson, A.-M. \& Wallander, H. (2003) Effects of hardened wood ash on microbial activity, plant growth and nutrient uptake by ectomycorrhizal spruce seedlings. FEMS Microbiology Ecology 43, 121-131.

Major, J., Steiner, C., Downie, A. \& Lehmann, J. (2009) Biochar effects on nutrient leaching. In Lehmann, J. \& Joseph, S. (eds), Biochar for environmental management, Earthscan, UK, pp. 271-287. 426-434. 
Marques, A. P. G. C., Rangel, A. O. S. S. \& Castro, P. M. L. (2009) Remediation of heavy metal contaminated soils: Phytoremediation as a potentially promising clean-up technology. Critical Reviews in Environmental Science and Technology 39, 622-654.

Mason, P. (2004) More to fungi than meets the eye. Forestry and British Timber 33, 20-26.

Mathews, J. A. (2008) Carbon-negative biofuels. Energy Policy 36, 940-945.

Matsubara, Y. -I., Hasegawa, N. \& Fukui, H. (2002) Incidence of fusarium root rot in asparagus seedlings infected with arbuscular mycorrhizal fungus as affected by several soil amendments. Journal of the Japanese Society for Horticultural Science 71, 370-374.

McGrath, K. C., Thomas-Hall, S. R., Cheng, C. T., Leo, L., Alexa, A., Schmidt, S. \& Schenk, P. M. (2008) Isolation and analysis of mRNA from environmental microbial communities. Journal of Microbiological Methods 75, 172-176.

McMahon, S.K., Wallenstein, M.D. \& Schimel, J. (2010) A cross-seasonal comparison of active and total bacterial community composition in Arctic tundra soil using bromodeoxyuridine labeling. Soil Biology and Biochemistry 43, 287-295.

Meharg, A. A. \& Cairney, J. W. G. (2000) Ectomycorrhizas - extending the capabilities of rhizosphere remediation? Soil Biology and Biochemistry 32, 1475-1484.

Metfies, K. \& Medlin, L. K. (2008) Feasibility of transferring fluorescent in situ hybridization probes to an 18S rRNA gene phylochip and mapping of signal intensities. Applied and Environmental Microbiology 74, 2814-2821.

Mexal, J. G. (1980) Aspects of mycorrhizal inoculation in relation to reforestation. New Zealand Journal of Forestry Science 10, 208-217.

Mikan, C.J. \& Abrams, M.D. (1996) Mechanisms inhibiting the forest development of historic charcoal hearths in south-eastern Pennsylvania. Canadian Journal of Forest Research 26, 1893-1898.

Molina, M., Zaelke, D., Sarma, K. M., Andersen, S. O., Ramanathan, V. \& Kaniaru, D. (2009) Reducing abrupt climate change risk using the montreal protocol and other regulatory actions to complement cuts 

in $\mathrm{CO}_{2}$ emissions. Proceedings of the National Academy of Sciences of the United States of America 106, 20616-20621.

Morris, D. R., Gilbert, R. A., Reicosky, D. C. \& Gesch, R. W. (2004) Oxidation potentials of soil organic matter in histosols under different tillage methods. Soil Science Society of America Journal 68, 817826.

Muyzer, G. \& Smalla, K. (1998) Application of denaturing gradient gel electrophoresis (DGGE) and temperature gradient gel electrophoresis (TGGE) in microbial ecology. International Journal of General and Molecular Microbiology 73, 127-141.

Neufeld, J. D. \& Murrell, J. C. (2007) Witnessing the last supper of uncultivated microbial cells with RamanFISH. ISME Journal 1, 269-270.

Neufeld, J. D., Wagner, M. \& Murrell, J. C. (2007) Who eats what, where and when? Isotope-labelling experiments are coming of age. ISME Journal 1, 103-110.

Nguyen, B. T. \& Lehmann, J. (2009) Black carbon decomposition under varying water regimes. Organic Geochemistry 40, 846-853. black carbon dynamics in cultivated soil. Biogeochemistry 92, 163-176.

Nguyen, T. H., Cho, H. -H., Poster, D. L. \& Ball, W. P. (2007) Evidence for a pore-filling mechanism in the adsorption of aromatic hydrocarbons to a natural wood char. Environmental Science and Technology 41, 1212-1217.

Nielsen, U.N., Ayres, E., Wall, D.H. \& Bardgett, R.D. (2011) Soil biodiversity and carbon cycling: A review and synthesis of studies examining diversity-function relationships. European Journal of Soil Science 62, 105-116. 
Oh, S., Yoder-Himes, D. R., Tiedje, J., Park, J. \& Konstantinidis, K. T. (2010) Evaluating the performance of oligonucleotide microarrays for bacterial strains with increasing genetic divergence from the reference strain. Applied and Environmental Microbiology 76, 2980-2988.

Onay, O. \& Koçkar, O. M. (2003) Slow, fast and flash pyrolysis of rapeseed. Renewable Energy 28, 2417 2433.

O'Neill, B., Grossman, J., Tsai, M. T., Gomes, J. E., Lehmann, J., Peterson, J., Neves, E. \& Thies, J. E. (2009) Bacterial community composition in Brazilian anthrosols and adjacent soils characterized using culturing and molecular identification. Microbial Ecology 58, 23-35.

Ortega-Calvo, J. -J. \& Saiz-Jimenez, C. (1998) Effect of humic fractions and clay on biodegradation of 10 phenanthrene by a Pseudomonas fluorescens strain isolated from soil. Applied and Environmental Microbiology 64, 3123-3126.

Ouverney, C. C. \& Fuhrman, J. A. (1999) Combined microautoradiography-16S rRNA probe technique for determination of radioisotope uptake by specific microbial cell types in situ. Applied and Environmental Microbiology 65, 1746-1752.

Özbay, N., Pütün, A. E. \& Pütün, E. (2001) Structural analysis of bio-oils from pyrolysis and steam pyrolysis of cottonseed cake. Journal of Analytical and Applied Pyrolysis 60, 89-101.

Özçimen, D. \& Ersoy-Meriçboyu, A. (2008) A study on the carbonization of grapeseed and chestnut shell. Fuel Processing Technology 89, 1041-1046.

Özçimen, D. \& Ersoy-Meriçboyu, A. (2010) Characterization of biochar and bio-oil samples obtained from carbonization of various biomass materials. Renewable Energy 35, 1319-1324.

21 Özçimen, D. \& Karaosmanoğlu, F. (2004) Production and characterization of bio-oil and biochar from rapeseed cake. Renewable Energy 29, 779-787.

23 Özyurtkan, M. H., Özçimen, D. \& Meriçboyu, A. E. (2008) Investigation of the carbonization behavior of hybrid poplar. Fuel Processing Technology 89, 858-863. 
1 Peng, X., Ye, L. L., Wang, C. H., Zhou, H. \& Sun. B. (2011) Temperature- and duration-dependent rice straw-derived biochar: characteristics and effects on soil properties of an ultisol in Southern China. Soil and Tillage Research, in press.

Penny, C., Nadalig, T., Alioua, M., Gruffaz, C., Vuilleumier, S. \& Bringel, F. (2010) Coupling of denaturing high-performance liquid chromatography and terminal restriction fragment length polymorphism with precise fragment sizing for microbial community profiling and characterization. Applied and Environmental Microbiology 76, 648-651.

Pietikäinen, J., Kiikkilä, O. \& Fritze, H. (2000) Charcoal as a habitat for microbes and its effect on the microbial community of the underlying humus. Oikos 89, 231-242.

Preston, T. R. (2009) Environmentally sustainable production of food, feed and fuel from natural resources in the tropics. Tropical Animal Health and Production 41, 873-882.

Probst, A., Vaishampayan, P., Osman, S., Moissl-Eichinger, C., Andersen, G. L. \& Venkateswaran, K. (2010) Diversity of anaerobic microbes in spacecraft assembly clean rooms. Applied and Environmental Microbiology 76, 2837-2845.

Prosser, J.I., Bohannan, B.J.M., Curtis, T.P., Ellis, R.J., Firstone, M.K., Freckleton, R.P., Green, J.L., Green, L.E., Killham, K., Lennon, J.J., Osborn, M.A., Solan, M., van der Gast, C.J. \& Young, P.W.J. (2007) Essay - the role of ecological theory in microbial ecology. Nature Reviews Microbiology 5, 384-392.

Purevsuren, B., Avid, B., Tesche, B. \& Davaajav, Y. (2003) A biochar from casein and its properties. Journal of Materials Science 38, 2347-2351.

Ramette, A. (2009) Quantitative community fingerprinting methods for estimating the abundance of operational taxonomic units in natural microbial communities. Applied and Environmental Microbiology 75, 2495-2505.

Rashid, A., Ayub, N., Ahmad, T., Gul, J. \& Khan, A. G. (2009) Phytoaccumulation prospects of cadmium and zinc by mycorrhizal plant species growing in industrially polluted soils. Environmental Geochemistry and Health 31, 91-98. 
Rillig, M. C., Wagner, M., Salem, M., Antunes, P. M., George, C., Ramke, H. -G., Titirici, M. -M. \& Antonietti, M. (2010) Material derived from hydrothermal carbonization: Effects on plant growth and arbuscular mycorrhiza. Applied Soil Ecology 45, 238-242.

4 Ritz, K. (2007) The Plate Debate: Cultivable communities have no utility in contemporary environmental microbial ecology. FEMS Microbiology Ecology 60, 358-362.

Roberts, K. G., Gloy, B. A., Joseph, S., Scott, N. R. \& Lehmann, J. (2010) Life cycle assessment of biochar systems: Estimating the energetic, economic, and climate change potential. Environmental Science and Technology 44, 827-833.

Rodríguez, L., Salazar, P. \& Preston, T. R. (2009) Effect of biochar and biodigester effluent on growth of maize in acid soils. Livestock Research for Rural Development 21, article number 110, available online: http://www.lrrd.org/lrrd21/7/rodr21110.htm (accessed 6/12/2010).

Rondon, M. A., Lehmann, J., Ramírez, J. \& Hurtado, M. (2007) Biological nitrogen fixation by common beans (Phaseolus vulgaris L.) increases with bio-char additions. Biology and Fertility of Soils 43, 699-

Rothberg, J.M. \& Leamon, J.H.(2008) The development and impact of 454 sequencing. Nature. Biotechnology. 26, 1117-1124.

Sait, M., Hugenholtz, P. \& Janssen, P.H. (2002) Cultivation of globally distributed soil bacteria from phylogenetic lineages previously only detected in cultivation-independent surveys. Environmental Microbiology 4, 654-666.

Samonin, V. V. \& Elikova, E. E. (2004) A study of the adsorption of bacterial cells on porous materials. Mikrobiologiya 73, 810-816.

Sánchez, M. E., Lindao, E., Margaleff, D., Martínez, O. \& Morán, A. (2009a) Pyrolysis of agricultural residues from rape and sunflowers: Production and characterization of bio-fuels and biochar soil management. Journal of Analytical and Applied Pyrolysis 85, 142-144. 
Sánchez, M. E., Lindao, E., Margaleff, D., Martínez, O. \& Morán, A. (2009b) Bio-fuels and bio-char production from pyrolysis of sewage sludge. Journal of Residuals Science and Technology 6, 35-42.

Schloss, P. D., Westcott, S. L., Ryabin, T., Hall, J. R., Hartmann, M., Hollister, E. B., Lesniewski, R. A., Oakley, B. B., Parks, D. H. Robinson, C. J., Shal, J. W., Stres, B., Thallinger, G. G., Van Horn, D. J. \& Weber, C. F.. (2009) Introducing mothur: Open-source, platform-independent, community-supported software for describing and comparing microbial communities. Applied and Environmental Microbiology 75, 7537-7541.

Schneegurt, M.A., Dore, S.Y. \& Kulpa, Jr., C.F. (2003) Direct extraction of DNA from soils for studies in microbial ecology. Current Issues in Molecular Biology 5, 1-8.

Schneider, T. \& Riedel, K. (2010) Environmental proteomics: Analysis of structure and function of microbial communities. Proteomics 10, 785-798.

Schwartz, E. (2007) Characterization of growing microorganisms in soil by stable isotope probing with $\mathrm{H}_{2}{ }^{18} \mathrm{O}$. Applied and Environmental Microbiology 73, 2541-2546.

Schwieger, F. \& Tebbe, C. C. (1998) A new approach to utilize PCR-single-strand-conformation polymorphism for 16S rRNA gene-based microbial community analysis. Applied and Environmental Microbiology 64, 4870-4876.

Sebastianelli, A., Sen, T. \& Bruce, I. J. (2008) Extraction of DNA from soil using nanoparticles by magnetic bioseparation. Letters in Applied Microbiology 46, 488-491.

Şensöz, S. (2003) Slow pyrolysis of wood barks from Pinus brutia Ten. and product compositions. Bioresource Technology 89, 307-311.

Shafizadeh, F. \& Sekiguchi, Y. (1983) Development of aromaticity in cellulosic chars. Carbon 21, 511-516.

Sharma, R. K., Wooten, J. B., Baliga, V. L., Lin, X., Chan, W. G. \& Hajaligol, M. R. (2004) Characterization of chars from pyrolysis of lignin. Fuel 83, 1469-1482.

Shaw, L. (2010) Biochar research at the University of Reading, Proceedings of the UKBRC. Rothamsted, $U K$, available online: http://www.geos.ed.ac.uk/sccs/biochar/Rothamsted (accessed 12/5/2010). 
Shaw, L. J. \& Hooker, J. E. (2008) The fate and toxicity of the flavonoids naringenin and formononetin in soil. Soil Biology and Biochemistry 40, 528-536.

3 Sheng, G., Yang, Y., Huang, M. \& Yang, K. (2005) Influence of pH on pesticide sorption by soil containing wheat residue-derived char. Environmental Pollution 134, 457-463.

Shinogi, Y. (2004) Nutrient leaching from carbon products of sludge, Proceedings of the ASAE Annual International Meeting 2004. Ottawa, Canada, 4951-4960.

Shrestha, P. M., Kube, M., Reinhardt, R. \& Liesack, W. (2009) Transcriptional activity of paddy soil bacterial communities. Environmental Microbiology 11, 960-970.

Singer, A. C., Huang, W. E., Helm, J. \& Thompson, I. P. (2005) Insight into pollutant bioavailability and toxicity using raman confocal microscopy. Journal of Microbiological Methods 60, 417-422.

Singh, N. \& Kookana, R. S. (2009) Organo-mineral interactions mask the true sorption potential of biochars in soils. Journal of Environmental Science and Health - Part B Pesticides, Food Contaminants, and Agricultural Wastes 44, 214-219.

Smith, J.L, Collins, H.P. \& Bailey, V.L. (2010a) The effect of young biochar on soil respiration. Soil Biology and Biochemistry 42, 2345-2347.

Smith, S. E., Christophersen, H. M., Pope, S. \& Smith, F. A. (2010b) Arsenic uptake and toxicity in plants: Integrating mycorrhizal influences. Plant and Soil 327, 1-21.

Sohi, S. P., Krull, E., Lopez-Capel, E. \& Bol, R. (2010) A review of biochar and its use and function in soil. Advances in Agronomy 105, 47-82.

Spokas, K. A., Koskinen, W. C., Baker, J. M. \& Reicosky, D. C. (2009) Impacts of woodchip biochar additions on greenhouse gas production and sorption/degradation of two herbicides in a Minnesota soil. Chemosphere 77, 574-581.

Steinbeiss, S., Gleixner, G. \& Antonietti, M. (2009) Effect of biochar amendment on soil carbon balance and soil microbial activity. Soil Biology and Biochemistry 41, 1301-1310. 
Steiner, C., Das, K. C., Garcia, M., Förster, B. \& Zech, W. (2007c) Charcoal and smoke extract stimulate the soil microbial community in a highly weathered Xanthic Ferralsol. Pedobiologia 51, 359-366.

Steiner, C., De Arruda, M. R., Teixeira, W. G. \& Zech, W. (2007b) Soil respiration curves as soil fertility indicators in perennial central Amazonian plantations treated with charcoal, and mineral or organic fertilisers. Tropical Science 47, 218-230.

Steiner, C., Teixeira, W. G., Lehmann, J., Nehls, T., De MacÊdo, J. L. V., Blum, W. E. H. \& Zech, W. (2007a) Long term effects of manure, charcoal and mineral fertilization on crop production and fertility on a highly weathered central Amazonian upland soil. Plant and Soil 291, 275-290.

Stevenson, B.S., Eichorst, S.A., Wertz, J.T., Schmidt, T.M. \& Breznak, J.A. (2004) New strategies for cultivation and detection of previously uncultured microbes. Applied and Environmental Microbiology 70, $4748-4755$.

Swift, R. S. (2001) Sequestration of carbon by soil. Soil Science 166, 858-871.

Tenenbaum, D. J. (2009) Biochar: Carbon mitigation from the ground up. Environmental Health Perspectives 117, 2.

Thies, J.E. \& Grossman, J.M. (2006) The soil habitat and soil ecology. In Uphoff, N., Ball, A.S., Fernandes, E., Herren, H., Husson, O., Liang, M., Palm, C., Pretty, J. \& Sanchez, P.A (eds) Biological approaches to sustainable soil systems. CRC Press, Boca Raton, pp. 59-78.

Thies, J. E. \& Rillig, M. C. (2009) Characteristics of biochar: Biological properties. In Lehmann, J. \& Joseph, S. (eds) Biochar for environmental management, science and technology. Earthscan, UK, pp. $85-106$.

Thies, J.E. \& Suzuki, K. (2003) Amazonian dark earths - biological measurements. In Lehmann, J., Kern, D., Glaser, B. \& Woods, W.I. (eds) Amazonian dark earths: Origin, properties and management. Kluwer Academic Publishing, Dordrecht, pp. 287-332.

Topoliantz, S., Ponge, J. -F. \& Ballof, S. (2005) Manioc peel and charcoal: A potential organic amendment for sustainable soil fertility in the tropics. Biology and Fertility of Soils 41, 15-21. 
Treseder, K. K. \& Allen, M. F. (2002) Direct nitrogen and phosphorus limitation of arbuscular mycorrhizal fungi: A model and field test. New Phytologist 155, 507-515.

Trompowsky, P. M., De Melo Benites, V., Madari, B. E., Pimenta, A. S., Hockaday, W. C. \& Hatcher, P. G. (2005) Characterization of humic like substances obtained by chemical oxidation of eucalyptus charcoal. Organic Geochemistry 36, 1480-1489.

Tyson, G.W. \& Banfield, J.F. (2005) Cultivating the uncultivated: A community genomics perspective. Trends in Microbiology 13, 411-415.

van der Gast, C.J., Gosling, P., Tiwari, B. \& Bending, G.D. (2010) Spatial scaling of arbuscular mycorrhizal fungal diversity is affected by farming practice. Environmental Microbiology 13, 241-249.

10

van Gestel, M., Ladd, J. N. \& Amato, M. (1991) Carbon and nitrogen mineralization from two soils of contrasting texture and microaggregate stability: Influence of sequential fumigation, drying and storage. Soil Biology and Biochemistry 23, 313-322.

van Herwijnen, R., Hutchings, T. R., Al-Tabbaa, A., Moffat, A. J., Johns, M. L. \& Ouki, S. K. (2007) Remediation of metal contaminated soil with mineral-amended composts. Environmental Pollution 150, 347-354.

van Zwieten, L., Kimber, S., Downie, A., Chan, K. Y., Cowie, A., Wainberg, R. and Morris, S. (2007) Papermill wate: Benefits to soil health and plant production. Proceedings of the Conference of the International Agrichar Initiative, 30 April - 2 May 2007, Terrigal, NSW, Australia.

van Zwieten, L., Kimber, S., Morris, S., Chan, K. Y., Downie, A., Rust, J., Joseph, S. \& Cowie, A. (2010) Effects of biochar from slow pyrolysis of papermill waste on agronomic performance and soil fertility. Plant and Soil 327, 235-246.

Vandenkoornhuyse, P., Dufresne, A., Quaiser, A., Gouesbet, G., Binet, F., Francez, A., Mahé, S., Bormans, M., Lagadeuc, Y. \& Couée, I. (2010) Integration of molecular functions at the ecosystemic level: Breakthroughs and future goals of environmental genomics and post-genomics. Ecology Letters 13, 776-791. 
Vassilev, A., Schwitzguebel, J. P., Thewys, T., Van Der Lelie, D. \& Vangronsveld, J. (2004) The use of plants for remediation of metal-contaminated soils. The Scientific World Journal 4, 9-34.

Ventura, M., Canchaya C., Tauch, A., Chandra, G., Fitzgerald, G.F., Chater, K.F. and van Sinderen, D. (2007) Genomics of Actinobacteria: Tracing the evolutionary history of an ancient phylum. Microbiology and Molecular Biology Reviews 71, 495-548.

Walker, J.M. (1993) Control of composting odors. In Hoitink, H.A.J. \& Keener, H.M. (eds) Science and engineering of composting: Design, environmental, microbiological and utilization aspects. Worthington: Renaissance Publications, pp. 185-218.

Wallstedt, A., Coughlan, A., Munson, A. D., Nilsson, M. -C. \& Margolis, H. A. (2002) Mechanisms of interaction between Kalmia angustifolia cover and Picea mariana seedlings. Canadian Journal of Forest Research 32, 2022-2031.

Wang, H. L., Lin, K. D., Hou, Z. N., Richardson, B. \& Gan, J. (2010) Sorption of the herbicide terbuthylazine in two New Zealand forest soils amended with biosolids and biochars. Journal of Soils and Sediments 10, 283-289.

Wang, S., Feng, Z. \& Wang, X. (2006) Effects of environmental pollutants on arbuscular mycorrhiza formation and function. Chinese Journal of Applied Ecology 17, 1321-1325.

Wang, S. -G., Lin, X. -G., Yin, R. \& Hou, Y. -L. (2004) Effect of inoculation with arbuscular mycorrhizal fungi on the degradation of DHEP in soil. Journal of Environmental Sciences 16, 458-461.

Wardle, D. A., Nilsson, M-C. and Zackrisson, O. (2008) Fire derived charcoal causes loss of forest humus. Science 320, 629.

Wardle, D. A., Zackrisson, O. \& Nilsson, M. -C. (1998) The charcoal effect in boreal forests: Mechanisms and ecological consequences. Oecologia 115, 419-426.

Warnock, D. D., Lehmann, J., Kuyper, T. W. \& Rillig, M. C. (2007) Mycorrhizal responses to biochar in soil - concepts and mechanisms. Plant and Soil 300, 9-20. 
Warnock, D.D., Mummey, D.L., McBride, B., Major, J., Lehmann, J. \& Rillig, M.C. (2010) Influences of non-herbaceous biochar on arbuscular mycorrhizal fungal abundances in roots and soils: Results from growth-chamber and field experiments. Applied Soil Ecology 46, 450-456.

4 Westerman, P. W. \& Bicudo, J. R. (2005) Management considerations for organic waste use in agriculture. Bioresource Technology 96, 215-221.

Wharfe, E. S., Jarvis, R. M., Winder, C. L., Whiteley, A. S. \& Goodacre, R. (2010) Fourier transform infrared spectroscopy as a metabolite fingerprinting tool for monitoring the phenotypic changes in complex bacterial communities capable of degrading phenol. Environmental Microbiology 12, 32533263.

Williams, S. E. \& Aldon, E. F. (1976) Endomycorrhizal (vesicular arbuscular) associations of some arid zone shrubs. The Southwestern Naturalist 20, 437-444.

Woolf, D., Amonette, J. E., Street-Perrott, F. A., Lehmann, J. and Joseph, S. (2010) Sustainable biochar to mitigate global climate change. Nature Commuications 1 (5), DOI: 10.1038/ncomms1053.

Worasuwannarak, N., Potisri, P. \& Tanthapanichakoon, W. (2006) Upgrading of biomass by carbonization in hot compressed water. Songklanakarin Journal of Science and Technology 28, 1049-1057.

Wu, J. \& Brookes, P. C. (2005) The proportional mineralisation of microbial biomass and organic matter caused by air-drying and rewetting of a grassland soil. Soil Biology and Biochemistry 37, 507-515.

Wu, N., Zhang, S., Huang, H. \& Christie, P. (2008a) Enhanced dissipation of phenanthrene in spiked soil by arbuscular mycorrhizal alfalfa combined with a non-ionic surfactant amendment. Science of the Total Environment 394, 230-236.

Wu, N., Zhang, S., Huang, H., Shan, X., Christie, P. \& Wang, Y. (2008b) DDT uptake by arbuscular mycorrhizal alfalfa and depletion in soil as influenced by soil application of a non-ionic surfactant. Environmental Pollution 151, 569-575.

Xu, M., Wu, W. -M., Wu, L., He, Z., Van Nostrand, J. D., Deng, Y., Luo, J., Carley, J., Ginder-Vogel, M., 
\& Zhou, J.. (2010) Responses of microbial community functional structures to pilot-scale uranium in situ bioremediation. ISME Journal 4, 1060-1070.

Yamato, M., Okimori, Y., Wibowo, I. F., Anshori, S. \& Ogawa, M. (2006) Effects of the application of charred bark of Acacia mangium on the yield of maize, cowpea and peanut, and soil chemical properties in South Sumatra, Indonesia. Soil Science and Plant Nutrition 52, 489-495.

Yang, Y. \& Sheng, G. (2003) Enhanced pesticide sorption by soils containing particulate matter from crop residue burns. Environmental Science and Technology 37, 3635-3639.

Yang, Y., Sheng, G. \& Huang, M. (2006) Bioavailability of diuron in soil containing wheat-straw-derived char. Science of the Total Environment 354, 170-178.

Yilmaz, O., Cem Kantarli, I., Yuksel, M., Saglam, M. \& Yanik, J. (2007) Conversion of leather wastes to useful products. Resources, Conservation and Recycling 49, 436-448.

Yip, K., Xu, M., Li, C-Z., Jiang, S. P. \& Wu, H. (2011) Biochar as a fuel: 3. Mechanistic understanding on biochar thermal annealing at mild temperatures and its effect on biochar reactivity. Energy and Fuels 25, 406-414.

Yu, C. -P., Ahuja, R., Sayler, G. \& Chu, K. -H. (2005) Quantitative molecular assay for fingerprinting microbial communities of wastewater and estrogen-degrading consortia. Applied and Environmental Microbiology 71, 1433-1444.

Yu, X., Pan, L., Ying, G. \& Kookana, R.S. (2010) Enhanced and irreversible sorption of pesticide pyrimethanil by soil amended with biochars. Journal of Environmental Sciences - Beijing 22, 615-620.

20

Yu, X. -Y., Ying, G. -G. \& Kookana, R. S. (2006) Sorption and desorption behaviour of diuron in soil amended with charcoal. Journal of Agricultural and Food Chemistry 54, 8545-8550.

Yu, X. -Y., Ying, G. -G. \& Kookana, R. S. (2009) Reduced plant uptake of pesticides with biochar additions to soil. Chemosphere 76, 665-671.

Zackrisson, O., Nilsson, M. -C. \& Wardle, D. A. (1996) Key ecological function of charcoal from wildfire in the boreal forest. Oikos 77, 10-19. 
1 Zhang, A., Ciu, L., Pan, G., Li, L., Hussain, Q., Zhang, X., Zheng, J. \& Crowley, D. (2010) Effect of biochar amendment on yield and methane and nitrous oxide emissions from rice paddy from Tai Lake plain, China. Agriculture, Ecosystem and Environment 139, 469-475.

4 Zhang, P., Sheng, G., Feng, Y. \& Miller, D. M. (2005) Role of wheat-residue-derived char in the biodegradation of benzonitrile in soil: Nutritional stimulation versus adsorptive inhibition. Environmental Science and Technology 39, 5442-5448.

7 Zhang, X. -H., Lin, A. -J. \& Cui, Y. -J. (2007) Effects of arbuscular mycorrhizal fungi on the toxicity of 8 chlorothalonil on upland rice (Oryzal sativa L.). Huanjing Kexue/Environmental Science 28, $1107-$ 1112

Zhou, J., He, Z., Van Nostrand, J.D., Wu, L. \& Deng, Y. (2010) Applying GeoChip analysis to disparate microbial communities. Microbe 5, 60-65.

12

13

14

15

Zhu, D., Kwon, S. \& Pignatello, J. J. (2005) Adsorption of single-ring organic compounds to wood charcoals prepared under different thermochemical conditions. Environmental Science and Technology 39, 39903998.

Zimmerman, A.R. (2010) Abiotic and microbial oxidation of laboratory- produced black carbon (biochar). Environmental Science and Technology 44, 1295-1301. 
1 Tables

2 Table 1: Biochar properties as a function of feedstock

\begin{tabular}{|c|c|c|c|c|c|c|c|c|c|}
\hline \multirow[t]{2}{*}{ Char } & \multirow[b]{2}{*}{$\begin{array}{l}\text { Temp } \\
/{ }^{\circ} \mathrm{C}\end{array}$} & \multirow[b]{2}{*}{$\begin{array}{l}\text { Carbon } \\
\text { content } \\
/ \mathrm{g} \mathrm{kg}^{-1}\end{array}$} & \multicolumn{4}{|c|}{ Proximate analysis } & \multirow[b]{2}{*}{$\begin{array}{l}\text { Surface } \\
\text { area } \\
/ \mathrm{m}^{2} \mathrm{~g}^{-1}\end{array}$} & \multirow[b]{2}{*}{$\begin{array}{l}\text { Cation } \\
\text { exchange } \\
\text { capacity } \\
/ \text { meq }(100 \mathrm{~g} \\
\text { soil })^{-1}\end{array}$} & \multirow[b]{2}{*}{ Author } \\
\hline & & & Yield / \% & $\begin{array}{l}\text { Volatiles } \\
/ \%\end{array}$ & $\begin{array}{l}\text { Fixed } \\
\text { carbon / } \\
\%\end{array}$ & $\begin{array}{l}\text { Ash } \\
/ \%\end{array}$ & & & \\
\hline Cellulosic char & 300 & 440 & & & & & & & Shafizadeh and Sekiguchi (1983) \\
\hline Wood & 350 & 673 & & & & & & & Baldock and Smernik (2002) \\
\hline $\begin{array}{l}\text { Corn (Zea } \\
\text { mays) residue }\end{array}$ & 350 & 675 & & & & & & & Nguyen and Lehmann (2009) \\
\hline $\begin{array}{l}\text { Pitch pine } \\
\text { (Pinus rigida) } \\
\text { wood }\end{array}$ & 450 & & & & & & $<10$ & & Brown et al. (2006) \\
\hline $\begin{array}{l}\text { Grapeseed } \\
\text { (Vitris vinifera) }\end{array}$ & 450 & & $49-53$ & & & & & & Özçimen \& Ersoy-Meriçboyu, (2008) \\
\hline $\begin{array}{l}\text { Chestnut shell } \\
\text { (Castanea } \\
\text { sativa Mill.) }\end{array}$ & 450 & & $55-60$ & & & & & & Özçimen \& Ersoy-Meriçboyu, (2008) \\
\hline
\end{tabular}




\begin{tabular}{|c|c|c|c|}
\hline Cellulosic char & 500 & 804 & \\
\hline $\begin{array}{l}\text { Rapeseed cake } \\
\text { (Brassica } \\
\text { napus L. ssp. } \\
\text { oleifare) }\end{array}$ & 500 & & \\
\hline $\begin{array}{l}\text { Poultry (Gallus } \\
\text { domesticus) } \\
\text { litter }\end{array}$ & 500 & & \\
\hline $\begin{array}{l}\text { Peanut (Arachis } \\
\text { hypogaea) hulls }\end{array}$ & 500 & & \\
\hline $\begin{array}{l}\text { Pine (Pinus } \\
\text { taeda) chips }\end{array}$ & 500 & & \\
\hline Switchgrass & 500 & & \\
\hline Corn stover & 500 & & \\
\hline Rape & 550 & & \\
\hline Sunflower & 550 & & \\
\hline $\begin{array}{l}\text { Grapeseed } \\
\text { (Vitris vinifera) }\end{array}$ & 550 & & $43-45$ \\
\hline $\begin{array}{l}\text { Chestnut shell } \\
\text { (Castanea } \\
\text { sativa Mill.) }\end{array}$ & 550 & & $48-50$ \\
\hline $\begin{array}{l}\text { Corn (Zea } \\
\text { mays) residue }\end{array}$ & 600 & 790 & \\
\hline $\begin{array}{l}\text { Pitch pine } \\
\text { (Pinus rigida) }\end{array}$ & 750 & & \\
\hline
\end{tabular}

\begin{tabular}{|c|c|c|c|c|c|}
\hline & & & & 38.3 & Gaskin et al. (2008) \\
\hline & & & & 4.63 & Gaskin et al. (2008) \\
\hline & & & & 5.03 & Gaskin et al. (2008) \\
\hline 7.1 & 39.5 & 52.5 & 50.2 & & Brewer et al. (2009) \\
\hline 11.1 & 54.7 & 32.4 & 20.9 & & Brewer et al. (2009) \\
\hline 13.6 & 64.6 & 21.8 & & & \\
\hline 13.4 & 57.7 & 28.9 & & & \\
\hline & & & & & $\begin{array}{l}\text { Özçimen \& Ersoy-Meriçboyu, } \\
(2008)\end{array}$ \\
\hline & & & & & $\begin{array}{l}\text { Özçimen \& Ersoy-Meriçboyu, } \\
\text { (2008) }\end{array}$ \\
\hline & & & & & Nguyen and Lehmann (2009) \\
\hline & & & 400 & & Brown et al. (2006) \\
\hline
\end{tabular}


Hardwood

$$
\text { unspecified }
$$

19.7
19.7

$7.7-7.9$
Brewer et al. (2009)

Boateng (2007)

Switchgrass

(Panicum

unspecified

\section{Boateng (2007)}




\begin{tabular}{|c|c|c|c|c|c|c|c|}
\hline Crop & $\begin{array}{l}\text { Trial } \\
\text { Type }\end{array}$ & Soil & Region & Biochar & $\begin{array}{l}\text { Application } \\
\text { Rate }\end{array}$ & Effect & Authors \\
\hline $\begin{array}{l}\text { Radish } \\
\text { (Raphanus } \\
\text { sativus) }\end{array}$ & Pot & Alfisol & Australasia & $\begin{array}{l}\text { Greenwaste } \\
\text { pyrolysis }\end{array}$ & ${ }_{1}^{10}-100 \mathrm{tha}^{-}$ & $\begin{array}{l}\text { At highest rates with nitrogen }\left(100 \mathrm{~kg} \mathrm{ha}^{-1}\right) \\
\text { application, }+280 \% \text { yield, compared to } \\
+95 \% \text { in absence of biochar }\end{array}$ & $\begin{array}{l}\text { Chan et al. } \\
(2007 \mathrm{a})\end{array}$ \\
\hline Radish & Pot & Alfisol & Australasia & $\begin{array}{l}\text { Poultry litter } \\
\text { pyrolysed at } \\
450 \text { and } 550 \\
{ }^{\circ} \mathrm{C}\end{array}$ & $\begin{array}{l}0-50 \mathrm{t} \mathrm{ha}^{-1} \\
+/-100 \mathrm{~kg} \mathrm{~N} \\
\mathrm{ha}^{-1}\end{array}$ & $\begin{array}{l}+42 \% \text { at } 10 \mathrm{tha}^{-1} \text { without } \mathrm{N} \\
+96 \% \text { at } 50 \mathrm{tha}^{-1} \text { without } \mathrm{N} \\
\text { with } \mathrm{N} \text {, lower temp material more effective }\end{array}$ & $\begin{array}{l}\text { Chan et al. } \\
(2008)\end{array}$ \\
\hline $\begin{array}{l}\text { Cherry } \\
\text { tomato }\end{array}$ & Pot & Chromosol & Australasia & $\begin{array}{l}\text { Wastewater } \\
\text { sludge } \\
\text { pyrolysed at } \\
550^{\circ} \mathrm{C}\end{array}$ & $10 \mathrm{tha}^{-1}$ & $64 \%$ & $\begin{array}{l}\text { Hossain et } \\
\text { al. (2010) }\end{array}$ \\
\hline Maize & Field & $\begin{array}{l}\text { Degraded } \\
\text { Amazonian }\end{array}$ & $\begin{array}{l}\text { South } \\
\text { America }\end{array}$ & & & Biochar doubled maize yield & $\begin{array}{l}\text { Kimetu et } \\
\text { al. (2008) }\end{array}$ \\
\hline Maize & Pot & $\begin{array}{l}\text { Top soil and } \\
\text { subsoil }\end{array}$ & $\begin{array}{l}\text { South } \\
\text { America }\end{array}$ & $\begin{array}{l}\text { Sugarcane } \\
\text { bagasse }\end{array}$ & $\begin{array}{l}50 \mathrm{~g} \mathrm{~kg}^{-1} \text { soil } \\
+/- \\
\text { biodigester } \\
\text { effluent }(100 \\
\left.\mathrm{kg} \mathrm{N} \mathrm{ha}^{-1}\right)\end{array}$ & $\begin{array}{l}\text { Biochar increased green biomass growth of } \\
\text { maize in top soil absence and presence of } \\
\text { effluent. Biochar increased green biomass in } \\
\text { presence of effluent in subsoil }\end{array}$ & $\begin{array}{l}\text { Rodríguez } \\
\text { et al. } \\
\text { (2009) }\end{array}$ \\
\hline $\begin{array}{l}\text { Wheat } \\
\text { Soybean } \\
\text { Radish }\end{array}$ & & $\begin{array}{l}\text { Ferrosol and } \\
\text { Calcerosol }\end{array}$ & Australasia & $\begin{array}{l}\text { Pyrolysed } \\
\text { papermill } \\
\text { waste }\end{array}$ & $10 \mathrm{tha}^{-1}$ & $\begin{array}{l}\text { Up to } 225 \% \text { increase in biomass production } \\
\text { (soybean only: negative responses for wheat } \\
\text { and soybean) }\end{array}$ & $\begin{array}{l}\text { van } \\
\text { Zwieten } e t \\
\text { al. }(2010)\end{array}$ \\
\hline
\end{tabular}


Rice (Oryza

sativa $\mathrm{L} ., \mathrm{cv}$

Wuyunjing

7)

China

10 and $40 \mathrm{t}$

ha $^{-1}$

Increase in rice yield of upto $14 \%$ in highest application rate and in the absence of

applied $\mathrm{N}$

Zhang et al

(2010)

Rice straw

pyrolysed at

$250-400^{\circ} \mathrm{C}$

for $2-8$

$1 \%$

\pm NPK

Increased maize yield of $146 \%$ in the

presence of NPK and $64 \%$ in its absence.

Peng et al ${ }^{3}$

(2011) 